\title{
Identification of a major QTL for time of initial vegetative budbreak in apple (Malus x domestica Borkh.).
}

Maria M. van Dyk ${ }^{1,4}$, M. Khashief Soeker ${ }^{1}$, Iwan F. Labuschagne ${ }^{2,3}$ and D. Jasper G. Rees ${ }^{1}$.

1-University of the Western Cape, Department of Biotechnology, Private Bag X17, Bellville, 7535, South Africa.

2-Agricultural Research Council (ARC) Infruitec-Nietvoorbij, Private Bag X5026, Stellenbosch, 7599, South Africa.

3-Colors Fruit (SA) (Pty) Ltd, 3rd Floor Newlink Centre, New Street, Paarl, 7646, South Africa

4- University of Pretoria, Department of Genetics, Lynwood Road, Pretoria, 0002, South Africa.

Correspondence author: daleen.vandyk@up.ac.za

\begin{abstract}
In the Western Cape region of South Africa dormancy release and the onset of growth does not occur normally in apple (Malus $\mathrm{x}$ domestica Borkh.) trees during spring due to the mild winter conditions experienced and fluctuations in temperatures experienced during and between winters. In this region the application of chemicals to induce the release of dormancy forms part of standard orchard management. Increasing awareness of the environmental impact of chemical sprays and global warming has led to the demand for new apple cultivars better adapted to local climatic conditions. We report the construction of framework genetic maps in two F1 crosses using the low chilling cultivar 'Anna' as common male parent and the higher chill requiring cultivars 'Golden Delicious' and 'Sharpe's Early' as female parents. The maps were constructed using 320 simple sequence repeats (SSR), including 116 new markers developed from expressed sequence tags (ESTs). These maps were used to identify quantitative trait loci (QTLs) for time of initial vegetative budbreak (IVB), a dormancy related characteristic. Time of IVB was assessed 4
\end{abstract}


times over a 6-year period in 'Golden Delicious' x 'Anna' seedlings kept in seedling bags under shade in the nursery. The trait was assessed for 3 years on adult full-sib trees derived from a cross between 'Sharpe's Early' and 'Anna' as well as for 3 years on replicates of these seedlings obtained by clonal propagation onto rootstocks. A single major QTL for time of IVB was identified on linkage group (LG) 9. This QTL remained consistent in different genetic backgrounds and at different developmental stages. The QTL may co-localize with a QTL for leaf break identified on LG 3 by Conner et al. (1998), a LG that was, after the implementation of transferable microsatellite markers, shown to be homologous to the LG now known to be LG 9 (Kenis and Keulemans, 2004). These results contribute towards a better understanding regarding the genetic control of IVB in aplle and will also be used to elucidate the genetic basis of other dormancy related traits such as time of initial reproductive budbreak and number of vegetative and reproductive budbreak.

\section{INTRODUCTION}

The domesticated apple (Malus $\mathrm{x}$ domestica Borkh.) has been distributed into diverse climatic conditions worldwide for commercial production of fruit. Apple trees need exposure to cold temperatures, referred to as chill unit (CU) accumulation during winter, in order for budbreak to occur promptly and uniformly after winter (Cook and Jacobs, 2000). In warmer production areas, such as the Western Cape region of South Africa, the application of dormancy breaking chemicals, forming part of standard orchard management, enable successful production of high chilling requiring apple cultivars in suboptimal environmental conditions. Failure to apply dormancy breaking chemicals can result in prolonged dormancy symptoms (PDS), which include extended rest, less synchronised breaking of buds and reduced branching (Labuschagné et al., 2002b). An increasing awareness of both global temperature increase and the negative effects associated with the use of chemical sprays (for both pest and disease resistance and growth regulation) has resulted in the need to breed cultivars better adapted to current and future environmental conditions.

The breeding of new cultivars using conventional breeding methods is a time consuming process, especially in perennial tree species with a long juvenile phase such as apple. 
Markers linked to genes involved in apple disease resistance for a variety of pests and pathogens have been identified (Gardiner et al., 2007) and are already in use in breeding programs (Kellerhals et al., 2008, Tartarini and Sansavini, 2003, Tartarini et al., 2000), through the implementation of marker-assisted-breeding (MAB) and selection (MAS) that enables the selection of favourable genotypes at a very early seedling stage. The genetic determinants of dormancy related characteristics, such as time of initial vegetative budbreak (IVB), are still poorly understood, and this hampers the genetic improvement of such characters using MAB. Dormancy characteristics can be controlled by factors residing within the bud itself, referred to as endodormancy, by factors in the plant but outside of the bud (paradormancy) and control by environmental factors (ectodormancy) (Khan, 1997, Lang et al., 1985). Although our study focused on time of IVB, a character related to endodormancy (Bradshaw and Stettler, 1995), various other characteristics can be associated with dormancy, such as position and number of budbreak and budbreak duration.

Unravelling of the genetic basis of complex traits such as dormancy, can be undertaken through the construction of a genetic linkage map followed by QTL identification (Falconer and Mackay, 1996, Young, 1996). A first attempt towards understanding the genetic control of 'leaf break' in apples through the identification of QTLs, was performed by Conner et al. (1998) using a population of 172 trees derived from a cross between 'Wijcik McIntosh' and NY 75441-58. Eight genomic regions on 7 linkage groups (LGs) could be associated with time of budbreak. The genetic linkage map constructed during their investigation, however did not include transferable simple sequence repeat (SSR) markers, resulting in their inability to align this map with the now more commonly used LG numbering for apple genetic linkage maps (Maliepaard et al., 1998). Further investigation resulted in alignment of three LGs from these two maps, including one (LG 3) that was homologous to LG 9 of Maliepaard et al. (1998) and carried a QTL for leaf break (Kenis and Keulemans, 2004). More recently Segura et al. (2007) used 123 seedlings derived from a cross between 'Starkrimson' and 'Granny Smith' to identify 2 QTLs for time of budbreak. The first on LG 8, corresponded to that identified on the corresponding LG 7 by Conner et al. (1998) (see Kenis and Keulemans, 2004). The second QTL for time of budbreak identified by Segura et al. (2007) was on LG 6. In the present study, genetic 
linkage maps were constructed for two mapping pedigrees with the low chilling requiring cultivar 'Anna' as common male parent. 'Anna' is one of only a few cultivars worldwide characterized by a low chilling requirement (CR) and with 'Dorsett Golden' was reported as varieties needing less than 300 hours of chilling in Southern California (http://ucce.ucdavis.edu/files/filelibrary/5764/33384.pdf) and North and North Central Florida (Andersen and Crocker, 2000). Both published SSR markers (Celton et al., 2009, Guilford et al., 1997, Hemmat et al., 2003, Hemmat et al., 1997, Liebhard et al., 2002, Silfverberg-Dilworth et al., 2006, Yamamoto et al., 2002a, Yamamoto et al., 2002b) and 116 new SSR markers, developed from expressed sequence tags (ESTs), were used for the construction of the genetic linkage maps used to identify a major QTL for time of IVB on LG 9.

\section{MATERIALS AND METHODS}

\section{Plant material.}

Two F1 progenies, derived from crosses between the low chilling 'Anna' (common male parent) and the higher chill requiring 'Golden Delicious' (population A) and 'Sharpe's Early' (population B), containing 87 and 92 individuals respectively, were used. Seedlings from population A were kept in seedling bags under shade netting in Groot Drakenstein

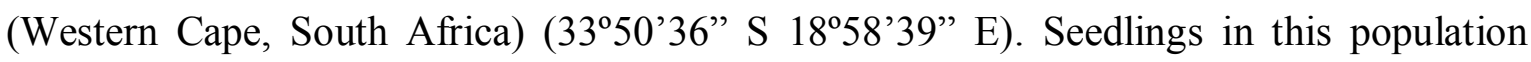
were cut back and re-grown to single shoots on a seasonal basis and no chemical treatment was used to induce budbreak. Seedlings from population B were planted in an orchard in

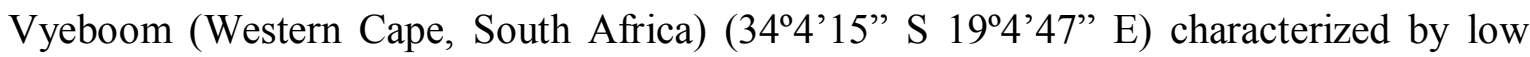
winter chilling. Resulting trees were in their $5^{\text {th }}$ growing season at the onset of this investigation. Seven clonal replicates from seedlings in population B and the two parental cultivars were grafted onto rootstocks (M793) and planted in 7 randomized blocks in an

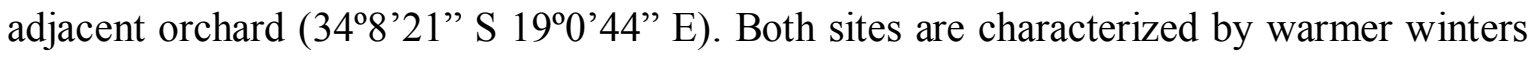
and fluctuating chilling accumulation between winters. At these sites chill unit (CU) accumulation varies between 500 and $1000 \mathrm{CU}$ annually. Chill units were calculated according to a modified Utah model found to be more suitable for local chilling conditions where negative $\mathrm{CU}$ values are not carried from one day to the next (Linsley-Noakes et al., 1994). Orchard management of adult and juvenile clonal trees from population B were 
typical of commercial practice, except that no pruning and tree growth manipulations, such as dormancy breaking chemicals, were applied.

\section{Phenotypic assessment.}

The time of initial vegetative budbreak (IVB) was scored as the day on which the first green leaves emerged from the vegetative buds (day 1 being the $1^{\text {st }}$ of January) (Labuschagné et al., 2002a, b). Phenotypic trait assessments were performed 4 times over a period of 6 years $(1999,2000,2002$ and 2004) on the 87 seedlings from population A. Trait assessment of population B was first performed during a 3 year period, from 1996 to 1998 , on 60 adult trees, initially in their $5^{\text {th }}$ growing season, followed by trait assessment on the 7 clonally replicated juvenile trees of all 92 siblings from 1998 to 2000. The data obtained from population B has been used in previous studies (Labuschagné et al., 2002a, b) during which broad sense heritability of IVB was estimated between 0.62 and 0.92 in clonal trials on young seedlings and between 0.57 and 0.83 for adult seedling trees. We calculated Pearson's correlation coefficients, to determine the relationship between different years of phenotypic trait assessment.

\section{DNA Extraction}

Extraction of seedling and parental cultivar DNA were performed using the CTAB method described by Doyle and Doyle (1990) with the addition of polyvinylpyrollidone (PVP) (Kim et al., 1997) in order to bind secondary plant products such as polyphenolics.

\section{SSR Marker development and implementation}

Unigene sets obtained from the large public EST database $(>240$ 000) (http://www.ncbi.nlm.nih.gov) (Naik et al., 2006, Newcomb et al., 2006) for Malus, were searched for SSRs using the Tandem Repeats Finder algorithm (Benson, 1999). SSRs were selected based on length of the repeat unit, number of repeats $(>10$ for di-, $>7$ for tri-, $>5$ for tetra- and penta- and $>3$ for hexanucleotide repeats) and length of sequences flanking SSR regions. Conserved sequences flanking 196 selected SSRs (100 di-, 60 tri-, 25 tetra-, 
5 penta- and 6 hexanucleotide repeats) were used to design primers resulting in amplicons ranging between 100 and $450 \mathrm{bp}$ in length. Newly developed SSR markers were tested on the three parental cultivars, 'Anna', 'Sharpe's Early' and 'Golden Delicious'. Markers for map construction were selected based on map position as well as heterozygosity observed during previous studies. They included 238 previously published SSR markers (Celton et al., 2009, Guilford et al., 1997, Hemmat et al., 2003, Hemmat et al., 1997, Liebhard et al., 2002, Silfverberg-Dilworth et al., 2006, Yamamoto et al., 2002a, Yamamoto et al., 2002b), marker AG11 (unpublished data: A. Patocchi (ETH-Zürich, CH)) and marker Md-EXP7 (Costa et al., 2008) and were initially screened for polymorphism over the three parental cultivars, 'Anna', 'Sharpe's Early' and 'Golden Delicious'.

\section{SSR Analysis}

All SSR markers implemented in mapping populations were fluorescently labelled and up to 16 markers were multiplexed using both size and fluorescent dye (6-FAM ${ }^{\text {ТM }}$, VIC ${ }^{\text {TM }}$, NE TM and PET TM) differences. PCR reactions were performed using the Qiagen multiplexing kit (QIAGEN Ltd., West Sussex, RH10 9NQ) according to the manufacturer's instructions. Resulting PCR products were prepared for capillary electrophoresis (CE) by adding $1 \mu \mathrm{l}$ of a 1:10 diluted PCR product to $10 \mu \mathrm{Hi}$-Di formamide containing $0.15 \mu \mathrm{l}$ GeneScan ${ }^{\mathrm{TM}}-500 \quad \mathrm{LIZ}^{\mathrm{TM}}$ size standard (Applied Biosystems). Genotyping was performed using the ABI Prism 310 and 3130 (16-capillary array system) Genetic Analyzers (Applied Biosystems, Foster City CA, USA). Data collection and analysis were performed using GeneMapper ${ }^{\circledR} 4$ software (Applied Biosystems, Foster City CA, USA).

\section{Genetic linkage map construction.}

For both progenies, parental genetic linkage maps and integrated genetic linkage maps were constructed using JoinMap ${ }^{\circledR} 4$ (Van Ooijen, 2006). A logarithm of the odds (LOD score) of 4 was used to define LGs and genetic distances between markers were calculated using the Kosambi mapping function. On the basis of previously mapped SSRs, LGs were numbered in accordance with the 17 LGs obtained by Maliepaard et al. (1998). 


\section{QTL analysis}

QTL analysis was performed using MapQTL $® 5$ (Van Ooijen, 2004) using the average phenotypic value for the four years of phenotypic trait assessment performed on population A and the two three year periods of trait assessment performed on adult and juvenile trees from population B. Analyses were also performed separately for each year of phenotypic trait assessment and in the case of clonal replicates the mean value per genotype was used. Regions with potential QTL effects were identified using interval mapping with a step size of $1 \mathrm{cM}$. QTLs were declared significant if the maximum LOD, obtained after multiple rounds of MQM mapping, exceeded the genome wide (GW) LOD threshold (calculated with an error rate of 0.05 over 1000 permutations). QTLs were characterized by the maximum LOD score and the percentage of phenotypic variation explained. For each QTL the differences in mean time of IVB associated with the different genotypic classes, ac, ad, bc and bd, derived for an ab x cd cross, are reported. QTLs were graphically displayed as bars next to the LGs on which they were identified, with bars corresponding to a $95 \%$ confidence interval (LOD score drop of 0.5 ) and dotted lines corresponding to a $90 \%$ confidence interval (LOD score drop of 1 ).

\section{RESULTS}

\section{Phenotypic trait assessment.}

Bi-modal distribution patterns were observed during most years of phenotypic trait assessment (Figure 1). The distribution patterns indicate budbreak was occurring earlier during consecutive years as trees matured. Significant levels of correlation were found between the different years during which phenotypic trait assessment were conducted (Table 1). High broad sense heritability values $\left(h^{2}=0.69\right)$ for IVB were calculated by Labuschagné et al. (2002a).

\section{SSR Marker development and implementation}

The amplification success of newly developed SSR markers was 86\% (168 SSRs from a total of 196). From these a total of 116 new SSR markers were polymorphic in at least one of the three parental cultivars used and were mapped in one or both mapping populations (Table 2). Of the 240 previously published markers, including 238 SSR markers (Celton et 
al., 2009, Guilford et al., 1997, Hemmat et al., 2003, Hemmat et al., 1997, Liebhard et al., 2002, Silfverberg-Dilworth et al., 2006, Yamamoto et al., 2002a, Yamamoto et al., 2002b), marker AG11 (unpublished data: A. Patocchi (ETH-Zürich, CH)) and marker Md-EXP7 (Costa et al., 2008), 232 markers yielded amplification products of which 204 markers were heterozygous in one or more of the three cultivars tested. Designing new SSR markers so that the resulting amplicons vary in size, enabled effective multiplexing of up to 16 markers in one PCR reaction, greatly reducing the cost involved in the screening of mapping populations. Markers used within each multiplex are very flexible when using the QIAGEN multiplexing kit (QIAGEN Ltd., West Sussex, RH10 9NQ) that provides optimal reaction conditions that increases specificity and minimizes the effect of primer-dimers and non-specific artifacts often associated with multiplex PCR reactions. The ease with which different multiplexes could be assembled enabled easy assembly of new multiplexes containing highly informative markers for each specific mapping pedigree.

\section{Genetic linkage map construction.}

The four parental maps constructed (Figure 2) enabled the positioning of 286 SSR markers on 17 LGs corresponding to the number of chromosomes in the apple haploid genome. The number of SSR markers per LG range from 10 SSR markers on LG 3 to 28 SSR markers on LG10, with an average of 17 SSR markers per LG. The positioning of the 116 newly developed SSR markers (Table 2) range from 2 SSR markers on LG 1 to 15 SSR markers on LG10.

Genetic linkage map construction allowed the positioning of five previously published but unmapped markers (Liebhard et al., 2002). CH01b09b was mapped to LG 4, CH01e09b was mapped to LG 10 and $\mathrm{CH} 02 \mathrm{~h} 11 \mathrm{~b}$ was mapped to LG 12 in both mapping populations. CH01e12 1 was mapped to LG 8 and $\mathrm{CH05c02}$ was mapped to LG 11 in the 'Golden Delicious' $x$ 'Anna' mapping population. Three markers were mapped to different LGs when compared to their location on previously published maps: (i) $\mathrm{CH} 03 \mathrm{e} 03$ was mapped to LG 5 compared to LG 3 (Liebhard et al. 2002), most likely due to the amplification of a different locus as observed fragment sizes are slightly larger than published (a fragment size of $216 \mathrm{bp}$ was observed in 'Prima' compared to the published 186bp), (ii) Hi23g12 
was mapped to LG 15 compared to LG 8 (Silfverberg-Dilworth et al., 2006) confirming results obtained by Patocchi et al. (2009); (iii) CH05d04 was mapped to LG 5 compared to LG 12 (Liebhard et al., 2002), also most likely due to the amplification of a different locus as observed fragment sizes are slightly smaller than published (fragments of 154 and 175 bp were observed in 'Prima' compared to the published 176 and $186 \mathrm{bp}$. The marker CH05g07 (Liebhard et al., 2002) was found to amplify 2 loci, both mapping to LG 12. A locus amplified by the marker Hi03a03 (Silfverberg-Dilworth et al., 2006) was confirmed to map onto LG 6 in both mapping populations used while a second locus amplified by the same marker was found to map to LG 14 in the 'Anna' $x$ 'Sharpe's Early' mapping population, confirming structural homology between LG 6 and LG14 (Celton et al., 2009).

\section{Population A.}

Of the 285 SSR markers screened on 87 seedlings from the 'Golden Delicious' x 'Anna' mapping pedigree, 260 markers were positioned on the integrated F1 genetic linkage map (map coverage: $1376.7 \mathrm{cM}$ ). Genetic linkage maps constructed for the parental cultivars 'Golden Delicious' (map coverage: $1124.5 \mathrm{cM}$ ) and 'Anna' (map coverage: $1292.6 \mathrm{cM}$ ) consisted of 163 (including 72 new SSRs) and 170 (including 71 new SSRs) markers, respectively. Parental maps were aligned using 92 SSR markers in common (Fig 2).

\section{Population B.}

The 'Sharpe's Early' x 'Anna' genetic map was constructed using 230 SSRs genotyped over the 92 F1 seedlings. The integrated F1 genetic linkage map (map coverage: 1242.6 cM) consisted of 207 mapped SSR markers. Genetic linkage maps constructed for the parental cultivars 'Sharpe's Early' (map coverage: $1012.9 \mathrm{cM}$ ) and 'Anna' (map coverage: $1050.6 \mathrm{cM}$ ) consisted of 127 (including 41 new SSRs) and 126 (including 45 new SSRs) markers respectively. Parental maps were aligned using 79 SSR markers in common (Fig 2). The parental map constructed for 'Anna' has 94 SSR markers in common with the parental map for 'Anna' constructed for population A.

\section{QTL detection and mapping}

A single major QTL for time of IVB was detected on LG 9 (Fig 3). Analyses performed on 
the average time of IVB for the different populations and developmental stages showed that this QTL exceeded the GW LOD threshold during phenotypic trait assessment performed on adult trees from population B. LOD scores obtained for the analyses performed on averages from population A and juvenile trees from population B were just below the GW LOD thresholds. Separate QTL analysis for the different years of phenotypic trait assessment performed on seedlings from population A resulted in $\mathrm{GW}$ LOD thresholds being reached during trait assessment performed on seedlings in their fourth (2002) and sixth (2004) year (Table 3). GW LOD thresholds were exceeded during all three years phenotypic trait assessment has been performed on adult trees from population B (Table 3). Separate QTL analysis for the three different years of phenotypic trait assessment performed on juvenile trees from population B resulted in GW LOD thresholds not being reached during the first three juvenile years (Table 3). One-way ANOVA indicated significant association $(\mathrm{P}<0.0001)$ between specific NZmsCN943946 alleles inherited from the parental cultivar 'Anna' and time of initial vegetative budbreak (IVB). This association was true during all years of phenotypic trait assessment on 'Golden Delicious' x 'Anna' $(30.22<\mathrm{F}>91.73)$ and 'Sharpe's Early' x 'Anna' adult $(34.39<\mathrm{F}>49.9)$ and juvenile $(30.6<\mathrm{F}>69.27)$ trees.

Differences in time of IVB associated with the four genotypic classes, ac, ad, bc and bd, derived from an ab $\mathrm{x}$ cd cross, indicate that the phenotypic variation can be associated with alleles inherited from the common male parent 'Anna'. This QTL explains between 4.8\% and $40.1 \%$ of the phenotypic variation observed in population $\mathrm{A}$ and between $11.9 \%$ and $44.6 \%$ of the phenotypic variation observed in population B.

\section{DISCUSSION}

The genetic linkage maps constructed are composed entirely of SSR markers and since a very large proportion of these markers are derived from EST sequences (more than 120) these maps are the most functional maps yet available. The newly developed and mapped SSR markers will enable the expansion of the $15 \mathrm{cM}$ reference map, currently consisting of 86 SSR markers covering $85 \%$ of the genome, proposed by Silfverberg-Dilworth et al. (2006) with up to 11 SSR markers. Depending on polymorphic information content determined on a larger number of cultivars, some of the newly developed SSR markers 
might be used to replace markers with low polymorphism now included in the reference set, due to lack of more polymorphic SSR markers in certain regions (Silfverberg-Dilworth et al., 2006).

The time of IVB showed a wide bi-modal distribution in the seedlings derived from both mapping populations. Although bi-modality could be explained by seedlings having a difference in their rapidity of response to favourable conditions after their CR was satisfied (Labuschagné et al., 2003), the distribution of time of IVB can be explained by the fact that the trait is controlled by a major QTL together with some minor QTLs. High heritability estimates, although specific to the experimental conditions in which they have been calculated, were calculated for time of IVB by both Labuschagné et al. (2002a) $\left(\mathrm{h}^{2}=\right.$ $0.69)$ and Segura et al. (2007) $\left(\mathrm{h}^{2}=0.58\right)$, indicating that the trait has a strong genetic influence and that it can be selected for using marker assisted selection. Heritability is not always related to the power of QTL detection (Segura et al., 2007), as the latter is also influenced by population size and the number of QTLs affecting the trait. The small number of individuals included in phenotypic trait assessment ( 87 from 'Golden Delicious' $\mathrm{x}$ 'Anna' and 60 and 92 for adults and juveniles from the 'Sharpe's Early' $\mathrm{x}$ 'Anna' mapping pedigrees) and the amount of variation observed among seedlings from the same mapping population, allowed for the detection of only one QTL with large effect. The fact that this QTL explains up to $40.1 \%$ and $44.6 \%$ of the phenotypic variation observed in populations A and B respectively, indicates that there are further QTLs affecting time of IVB. These may include several QTLs with smaller effect that are statistically not detectable due the restricted population sizes used and the phenotypic variation observed in the seedlings. During initial interval mapping (van Dyk et al., 2009) the involvement of several minor QTLs were suggested. Implementation of more markers leading to better genome coverage and the ability to perform MQM analysis, enabled the identification of a QTL with large effect in the current study.

Genetic linkage maps constructed for both mapping populations enabled the efficient detection of a major QTL affecting the time of IVB on LG 9 (Table 3). This QTL may co-localize with one of eight QTLs involved in leaf break that was identified by Conner et al. (1998). The QTL identified on LG 3 of the genetic linkage map produced by Conner et al. (1998) was, after the implementation of transferable microsatellite markers, shown to 
be homologous to the LG now known to be LG 9 (Kenis and Keulemans, 2004). In the present study the QTL on LG 9 can be associated with specific allele inheritance from the common parent 'Anna'. Performing QTL analyses on an integrated parental map when working with an outbreeder, as was done during this study, enables the determination of both the effect of alleles inherited from a single parent and the interaction between alleles inherited from both parents. Results (Table 3) indicated a clear difference in average time of IVB between seedlings that inherited allele "c" from 'Anna' (average "ac" and "bc") compared to seedlings that inherited allele "d" from 'Anna' (average "ad" and "bd"). No clear difference could be detected between seedlings that inherited different alleles from the other parental cultivar involved in each mapping pedigree or seedlings with a specific combination of parental alleles.

The power of QTL detection (LOD score) increased during consecutive years of phenotypic trait assessment being performed on seedlings from population A and juvenile trees from population B. This suggests that although the QTL can be associated with time of IVB in young seedlings, the association between the QTL and the trait becomes stronger as the tree matures. The QTL was found to be significant (LOD score exceeding GW LOD thresholds) in all three years during which phenotypic trait assessment was performed on adult trees from population B (Table 3). Although significant GW LOD thresholds are not met in juvenile trees from population B, the association between the QTL and time of IVB can be seen from obtained phenotypic means associated with each of the genotypic classes (Table 3). Budbreak occurring earlier as trees mature has not been reported before. Preliminary results suggest no correlation between the earlier time of vegetative budbreak, associated with seedling age in two apple populations studied, and the CU accumulated during different years. These results suggest that the chilling requirement (CR), which is the major determinant of time of budbreak (Bradshaw and Stettler, 1995), has been met and that the time of vegetative budbreak is also influenced by factors associated with tree age. These results need to be confirmed in future studies, including several years of phenotypic trait assessment performed during different developmental stages and on different populations.

Markers linked to the QTL identified will be used in a validation test on a larger progeny sharing common parentage. The QTL region will be saturated with markers selected for 
their positioning on the genetic linkage map as a result of selective (bin) mapping on a subset of individuals (van Dyk and Rees, 2009). The ideal will be the identification of markers flanking the QTL that can be used for the implementation of MAS in breeding for cultivars that are better adapted to local climatic conditions.

\section{ACKNOWLEDGEMENTS}

We would like to thank the Deciduous Fruit Producers Trust (DFPT), the Department of Trade and Industry (DTI-THRIP) and the National Research Foundation (NRF) for financial support. Thank you to Dr. Jean-Marc Celton and Dr. W.E. van de Weg for useful discussion regarding mapping. We are especially grateful to Prof. B. D. Wingfield from the University of Pretoria for the use of facilities.

\section{References}

1. Andersen, P. C., and T. E. Crocker. 2000. Low chill apple cultivars for north and north central Florida, University of Florida Extension. Institute for food and agricultural sciences.

2. Benson, G. 1999. Tandem repeats finder: a program to analyze DNA sequences. Nucleic Acids Research 27:573-580.

3. Bradshaw, B. D. J., and R. F. Stettler. 1995. Molecular genetics of growth and development in Populus. IV. Mapping QTLs with large effects on growth, form and phenology traits in a forest tree. Genetics 139:963-973.

4. Celton, J.-M., D. S. Tustin, D. Chagne, and S. E. Gardiner. 2009. Construction of a dense genetic linkage map for apple rootstocks using SSRs developed from Malus ESTs and Pyrus genomic sequences. Tree Genetics and Genomes 5:93-107.

5. Conner, P. J., S. K. Brown, and N. F. Weeden. 1998. Molecular-marker analysis of quantitative traits for growth and development in juvenile apple trees. Theoretical and Applied Genetics 96:1027-1035.

6. Cook, N. C., and G. Jacobs. 2000. Progression of apple (Malus x domestica Borkh.) bud dormancy in two mild winter climates. The Jounal of Horticultural Science and Biotechnology 75:233-236.

7. Costa, F., W. E. Van de Weg, S. Stella, L. Dondini, D. Pratesi, S. Musacchi, and S. Sansavini. 2008. Map position and functional allelic diversity of Md-Exp7, a new putative expansin gene associated with fruit softening in apple (Malus $\mathrm{x}$ domestica Borkh.) and pear (Pyrus communis). Tree Genetics and Genomes 4:575-586.

8. Doyle, J. J., and J. L. Doyle. 1990. Isolation of plant DNA from fresh tissue. Focus 12:13-15.

9. Falconer, D. S., and T. F. C. Mackay. 1996. Introduction to quantitative genetics, 4th ed. Pearson, England.

10. Gardiner, S., V. G. M. Bus, R. L. Rusholme, D. Chagne, and E. H. A. Rikkerink. 2007. Apple, p. 1-62. In C. Kole (ed.), Genome mapping and molecular breeding in 
plants. Fruits and Nuts, vol. 4. Springer-Verlag, Berlin Heidelberg.

11. Guilford, P., S. Prakash, J. M. Zhu, E. Rikkerink, S. Gardiner, H. Bassett, and R. Forster. 1997. Microsatellites in Malus $\mathrm{x}$ domestica (apple): abundance, polymorphism and cultivar identification. Theoretical and Applied Genetics 94:249-254.

12. Hemmat, M., N. F. Weeden, and S. K. Brown. 2003. Mapping and evaluation of Malus $\mathrm{x}$ domestica microsatellites in apple and pear. Journal of the American Society for Horticultural Science 128:515-520.

13. Hemmat, M., N. F. Weeden, P. J. Conner, and S. K. Brown. 1997. A DNA marker for columnar growth habit in apple contains a simple sequence repeat. Journal of the American Society for Horticultural Science 122:347-349.

14. Kellerhals, M., A. Patocchi, B. Duffy, and J. Frey. 2008. Presented at the Ecofruit 13th International conference on cultivation technique and phytopathological problems in organic fruit-growing, Weinsberg, Germany.

15. Kenis, K., and J. Keulemans. 2004. QTL Analysis of growth characterisitcs in apple, p. 369-374, Eucarpia symposium on fruit breeding and genetics, vol. 663. Acta Horticulturae 663:369-374, Angers, France.

16. Khan, A. A. 1997. Quantification of plant dormancy: introduction to the workshop. HortScience 32:608-614.

17. Kim, C. S., C. H. Lee, J. S. Shin, Y. S. Chung, and N. I. Hyung. 1997. A simple and rapid method for isolation of high quality genomic DNA from fruit trees and conifers using PVP. Nucleic Acids Research 25:1085-1086.

18. Labuschagné, I. F., J. H. Louw, K. Schmidt, and A. Sadie. 2003. Budbreak number in apple seedlings as selection criterion for improved adaptability to mild winter climates. HortScience 38:1186-1190.

19. Labuschagné, I. F., J. H. Louw, K. Schmidt, and A. Sadie. 2002a. Genetic variation in chilling requirement in apple progeny. Journal of the American Society for Horticultural Science 127:663-672.

20. Labuschagné, I. F., J. H. Louw, K. Schmidt, and A. Sadie. 2002b. Genotypic variation in prolonged dormancy symptoms in apple families. HortScience 37:157-163.

21. Lang, G. A., J. D. Early, N. J. Arroyave, R. L. Darnell, G. C. Martin, and G. W. Stutte. 1985. Dormancy: towards a reduced, universal terminology. HortScience 20:809-812.

22. Liebhard, R., L. Gianfranceschi, B. Koller, C. D. Ryder, R. Tarchini, E. Van de Weg, and C. Gessler. 2002. Development and characterisation of 140 new microsatellites in apple (Malus $\mathrm{x}$ domestica Borkh.). Molecular Breeding 10:217-241.

23. Linsley-Noakes, G. C., P. Allan, and G. Matthee. 1994. Modification of rest completion prediction models for improved accuracy in South African stone fruit orchards. Journal of South African Horticultural Science 4:13-15.

24. Maliepaard, C., F. H. Alston, G. Van Arkel, L. M. Brown, E. Chevreau, F. Dunemann, K. M. Evans, S. Gardiner, P. Guilford, A. W. Vand Heusden, J. Janse, F. Laurens, J. R. Lynn, A. G. Manganaris, A. P. M. Den Nijs, N. Periam, R. E., P. Roche, C. Ryder, S. Sansavini, H. Schmidt, S. Tartarini, J. J. Verhaegh, M. Vrielink-van Ginkel, and G. J. King. 1998. Aligning male and female linkage maps of apple (Malus pumila Mill.) using multi-allelic markers. Theoretical and Applied 
Genetics 97:60-73.

25. Naik, S., C. Hampson, K. Gasic, G. Bakkeren, and S. S. Korban. 2006. Development and linkage mapping of E-STS and RGA markers for functional gene homologues in apple. Genome 49:959-968.

26. Newcomb, R. D., R. N. Crowhurst, A. P. Gleave, E. H. A. Rikkerink, A. C. Allan, L. L. Beuning, J. H. Bowen, E. Gera, K. R. Jamieson, B. J. Janssen, W. A. Laing, S. McArtney, B. Nain, G. C. Ross, S. K. C., E. J. F. Souleyre, E. F. Walton, and Y.-K. Yauk. 2006. Analysis of expressed sequence tags from apple (Malus X domestica). Plant Physiology 141:1-20.

27. Patocchi, A., F. Fernandez-Fernanadez, K. Evans, D. Gobbin, F. Rezzonico, A. Boudichevskaia, F. Dunemann, M. Stankiewicz-Kosyl, F. Mathis-Jeanneteau, C. E. Durel, L. Gianfranceschi, F. Costa, C. Toller, V. Cova, D. Mott, M. Komjane, E. Barbaro, L. Kodde, E. Rikkerink, C. Gessler, and W. E. Van de Weg. 2009. Development and test of 21 multiplex PCRs composed of SSRs spanning most of the apple genome. Tree Genetics and Genomes 5:211-223.

28. Segura, V., C. Denance, C. E. Durel, and E. Costes. 2007. Wide range QTL analysis for complex architectural traits in a 1-year-old apple progeny. Genome 50:159-171.

29. Silfverberg-Dilworth, E., C. L. Matasci, W. E. Van de Weg, M. P. W. Van Kaauwen, M. Walser, L. P. Kodde, V. Soglio, L. Gianfranceschi, C. E. Durel, F. Costa, T. Yamamoto, B. Koller, C. Gessler, and A. Patocchi. 2006. Microsatellite markers spanning the apple (Malus x domestica Borkh.) genome, p. 202-224, Tree Genetics and Genomes, vol. 2.

30. Tartarini, S., and S. Sansavini. 2003. The use of molecular markers in pome fruit breeding. Acta Hort 622:129-132.

31. Tartarini, S., S. Sansavini, B. A. Vinatzer, F. Gennari, and C. Domizi. 2000. Efficiency of marker assisted selection (MAS) for the Vf scab resistance gene. Acta Hort 538:549-553.

32. van Dyk, M. M., I. F. Labuschagne, and D. J. G. Rees. 2009. Genetic Linkage Map construction and Identification of QTLs Affecting time of Initial Vegetative Budbread in Apple (Malus x domestica Borkh.). Acta Hort 814:586-590. 
33. van Dyk, M. M., and D. J. G. Rees. 2009. Bin Mapping of EST-SSRs in Apple (Malus x domestica Borkh.). Acta Hort 814:681-687.

34. Van Ooijen, J. W. 2006. JoinMap ${ }^{\circledR}$ 4. Software for the calculation of genetic linkage maps in experimental populations. Kyazma B. V., Wageningen, Netherlands.

35. Van Ooijen, J. W. 2004. MapQTL ${ }^{\circledR}$ 5, Software for the mapping of quantitative trait loci in experimental populations. Kyazma B. V., Wageningen, Netherlands.

36. Yamamoto, T., T. Kimura, Y. Sawamura, T. Manabe, K. Kotobuki, T. Hayashi, Y. Ban, and N. Matsuta. 2002a. Simple sequence repeats for genetic analysis in pear. Euphytica 124:129-137.

37. Yamamoto, T., T. Kimura, M. Shoda, Y. Ban, T. Hayashi, and N. Matsuta. 2002b. Development of microsatellite markers in the Japanese pear (Pyrus pyrifolie Nakai). Molecular Ecology Notes 2:14-16.

38. Young, N. D. 1996. QTL mapping and quantitative disease resistance in plants. Annual Review of Phytopathology 34:479-501. 

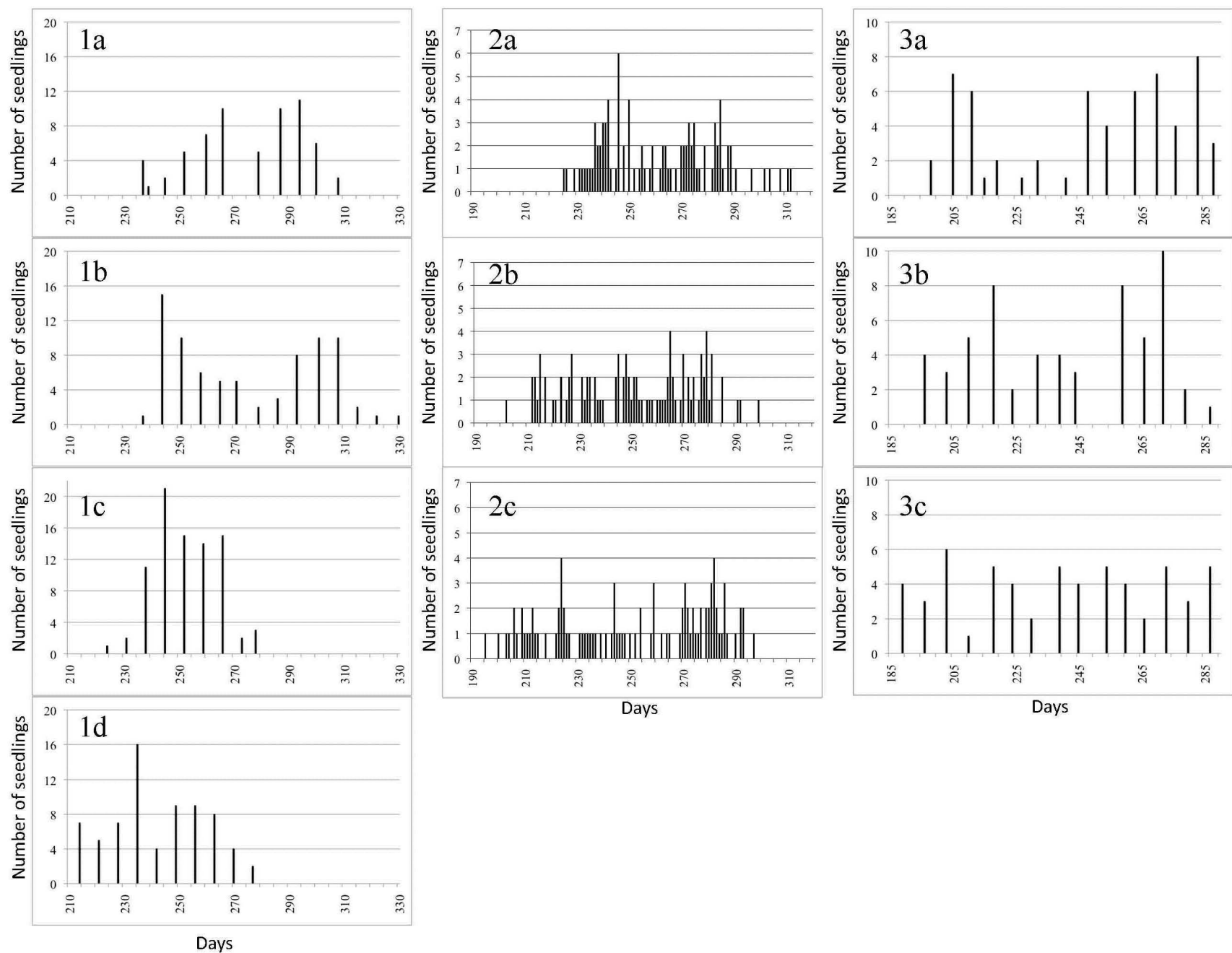

Figure 1: Histogram showing the distribution of time of initial vegetative budbreak (IVB) observed in 1: 'Golden Delicious' $\mathrm{x}$ 'Anna' seedlings during 4 years of phenotypic trait assessment $\mathrm{a}=1999, \mathrm{~b}=2000, \mathrm{c}=2002$ and $\mathrm{d}=2004 ; 2$ : 'Sharpe's Early' $\mathrm{x}$ 'Anna' juvenile trees during 3 years of phenotypic trait assessment $\mathrm{a}=1998, \mathrm{~b}=1999$ and $\mathrm{c}=$ 2000; and 3: 'Sharpe's Early' $x$ 'Anna' adult trees during 3 years of phenotypic trait assessment $\mathrm{a}=1996, \mathrm{~b}=1997$ and $\mathrm{c}=1998$. 


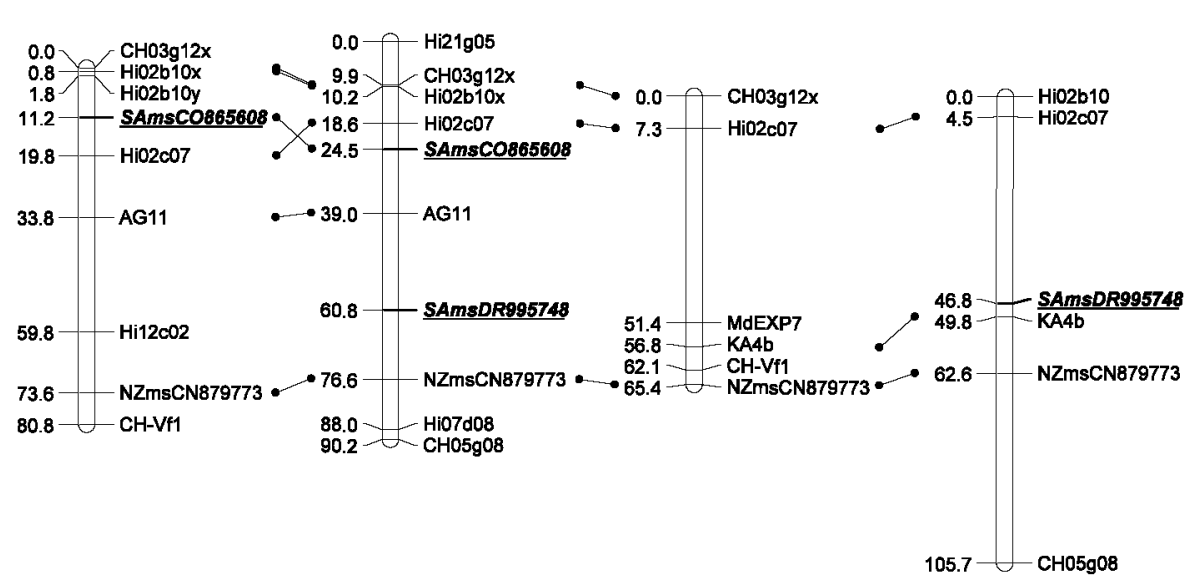

\section{GD LG5}

\section{Anna LG5}

SE LG5

Anna* LG5

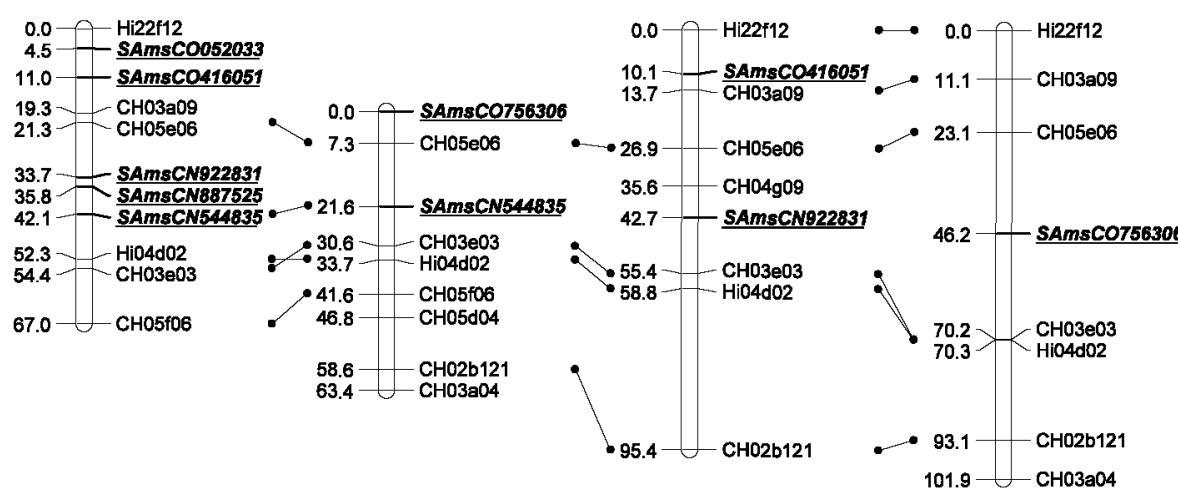

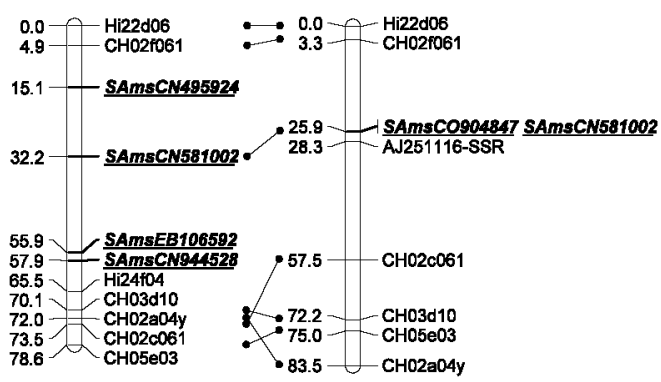

GD LG3

Anna LG3

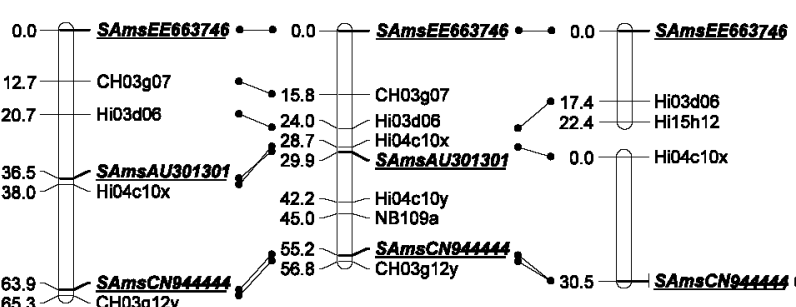

GD LG4

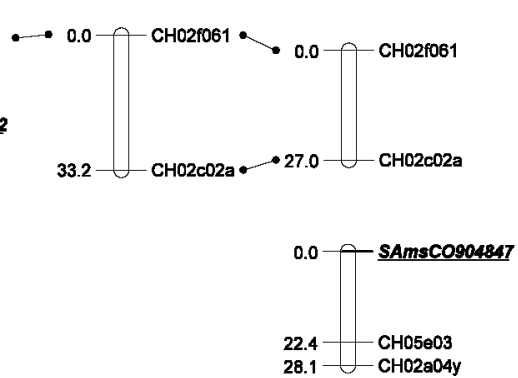

SE LG3

Anna* LG3

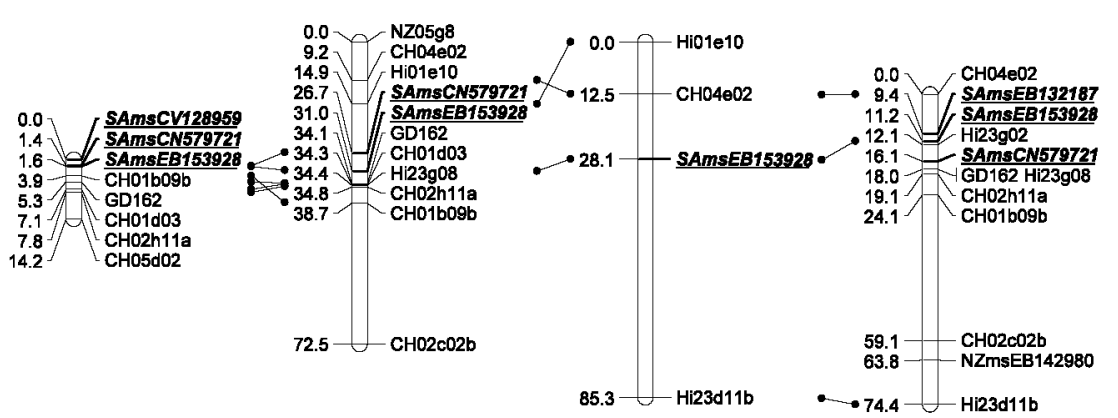




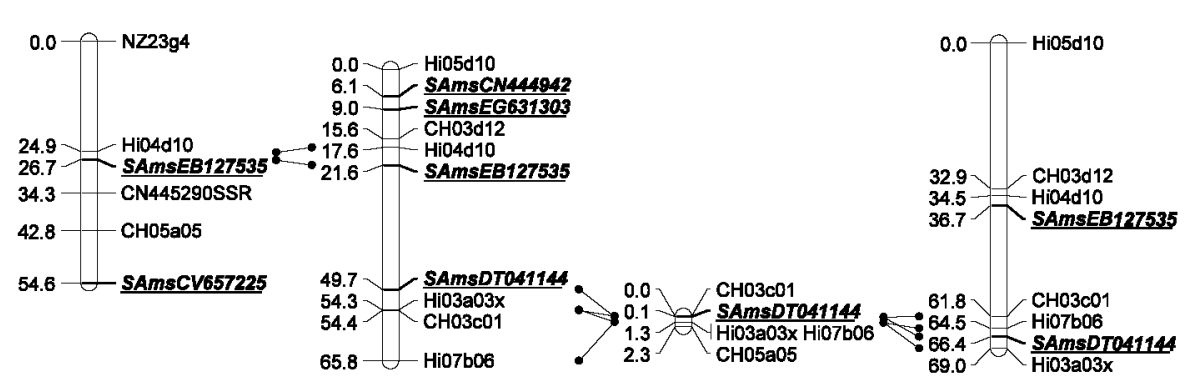

GD LG8 Anna LG8

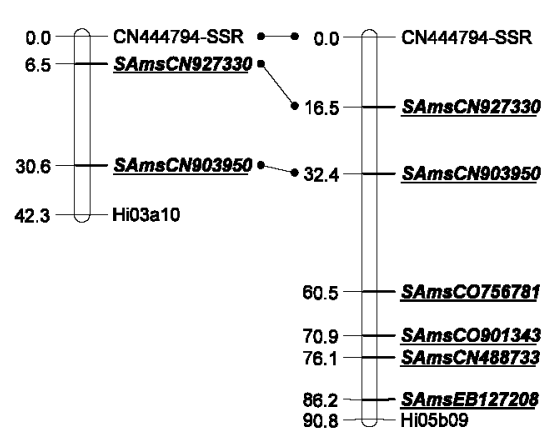

$0.0-\underline{\text { SAmsC0756781 }}$

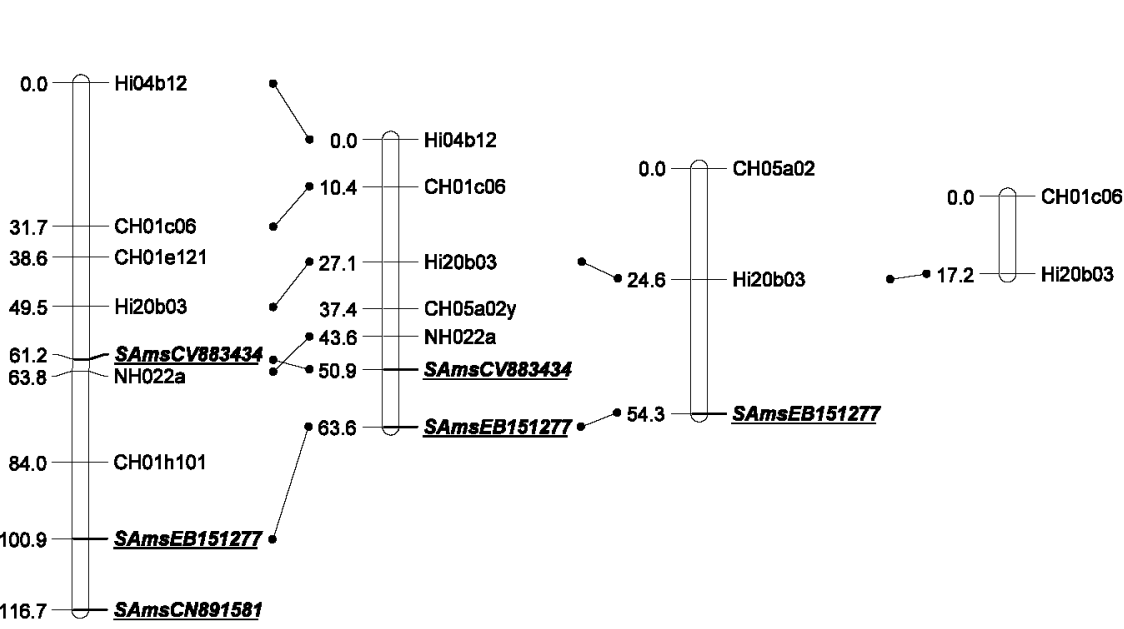
GD LG9
Anna LG9
SE LG9
Anna* LG9

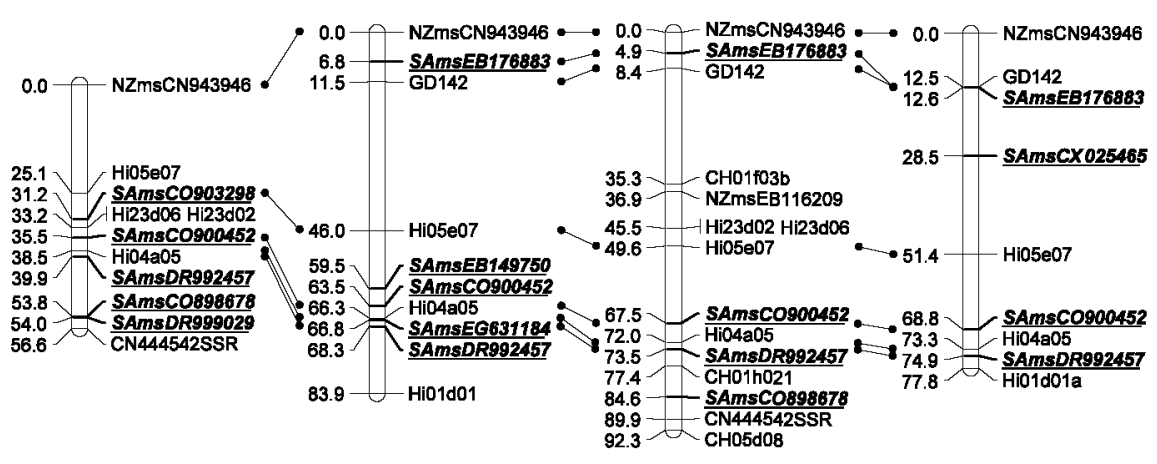




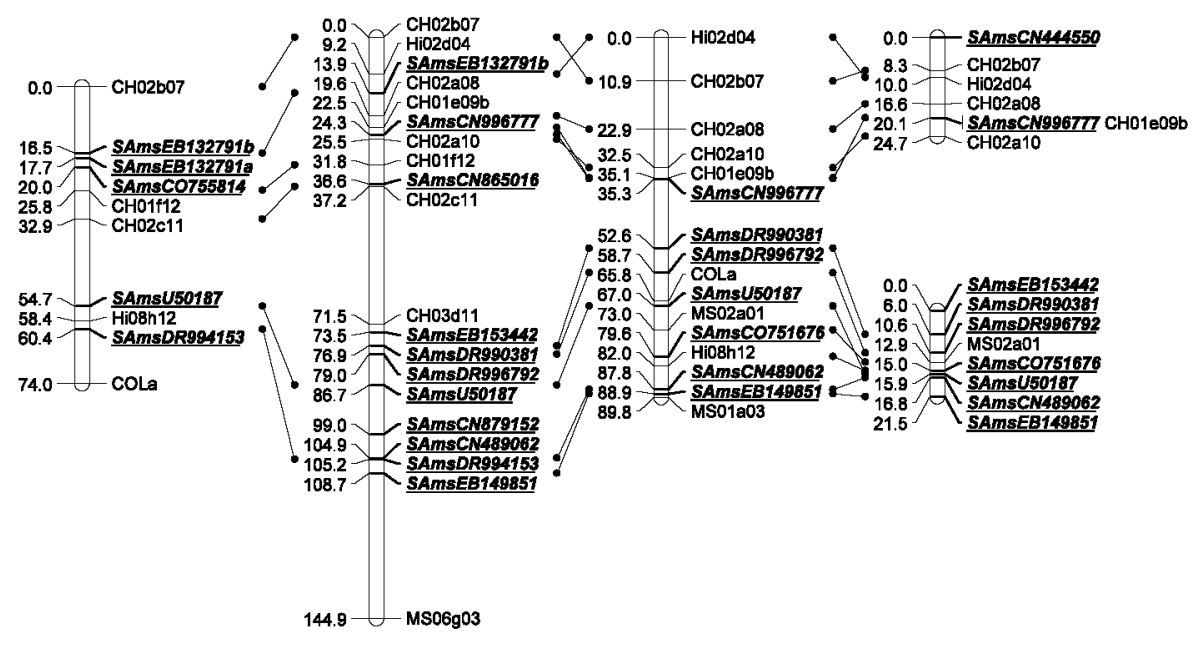

\section{$\begin{array}{llll}\text { GD LG12 } & \text { Anna LG12 } & \text { SE LG12 } & \text { Anna* LG12 }\end{array}$}

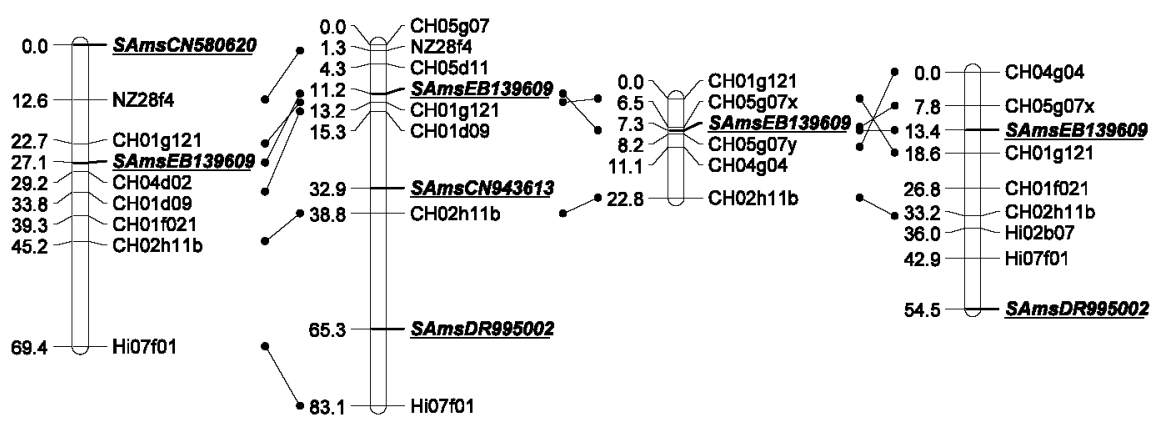

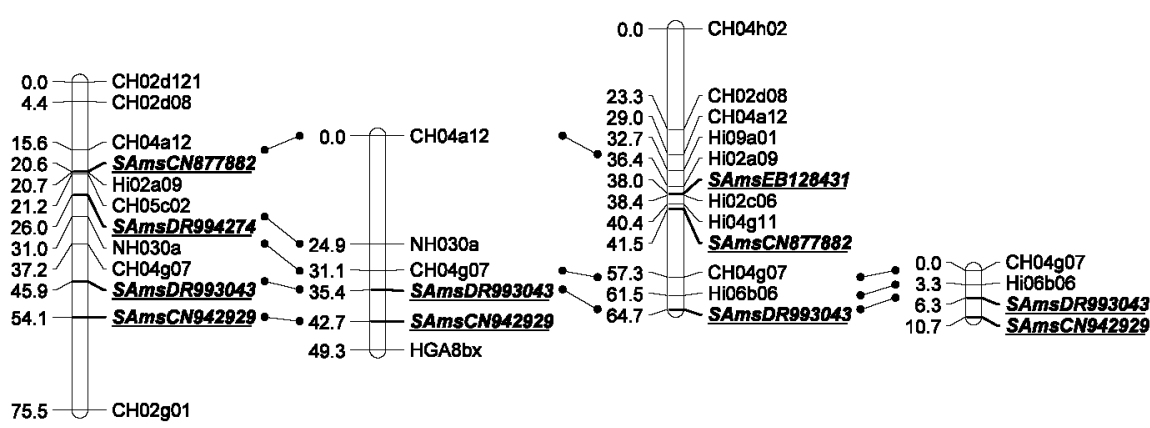

GD LG13 Anna LG13 Anna* LG13

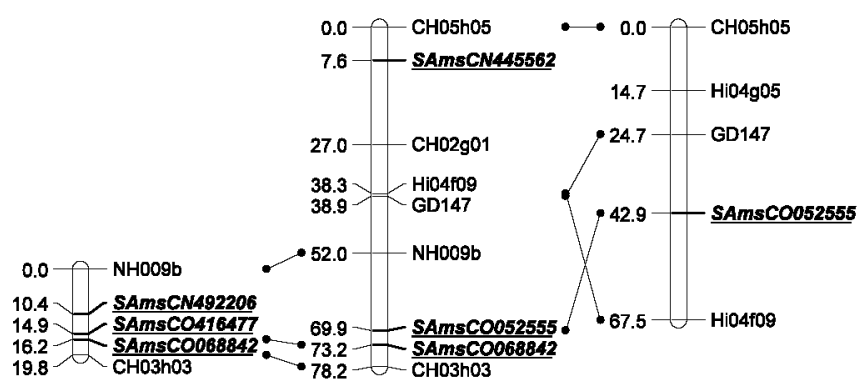

$\begin{array}{llll}\text { GD LG14 } & \text { Anna LG14 } & \text { SE LG14 } & \text { Anna* LG14 }\end{array}$

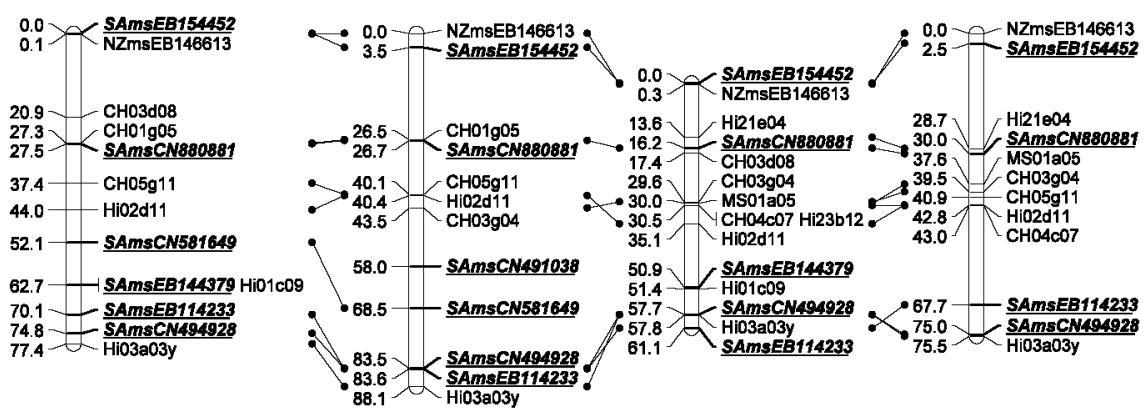




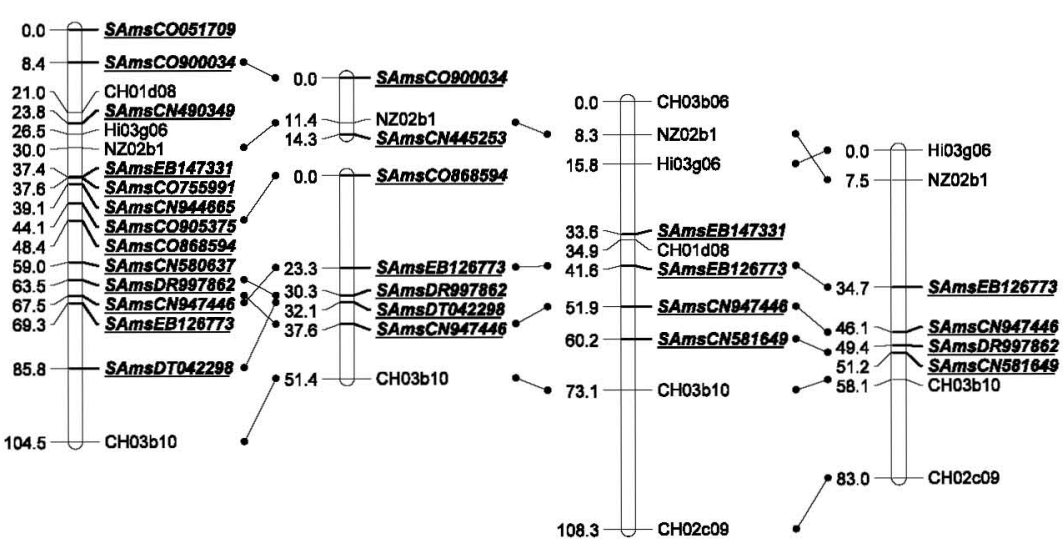

GD LG17

Anna LG17

SE LG17

Anna* LG17

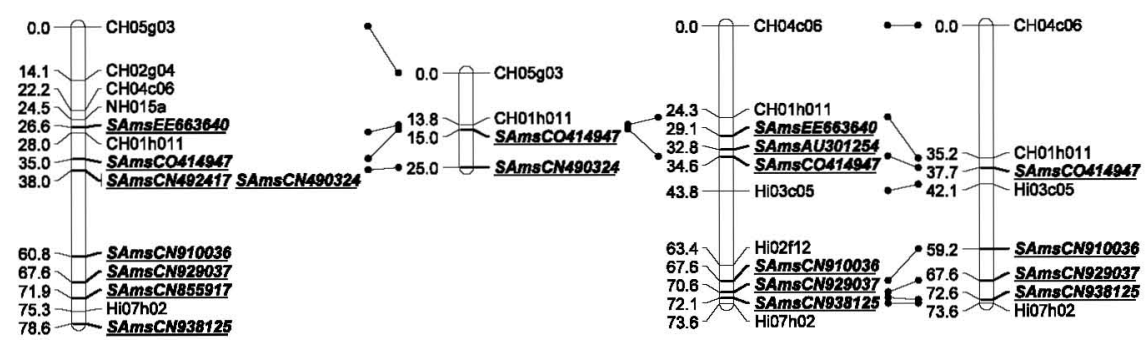

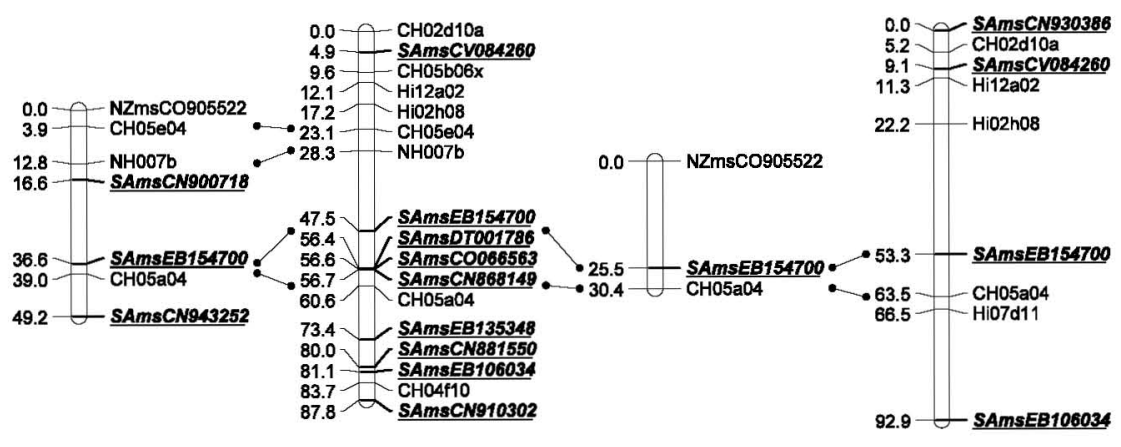

Figure 2: Parental genetic linkage maps of 'Golden Delicious' (GD) and 'Anna' from population A and 'Sharpe's Early' (SE) and 'Anna*' from population B. Numbering of LGs are according to Maliepaard et al. (1998). Newly developed SSRs are prefixed by SAms and are indicated in bold, italic and underlined. 


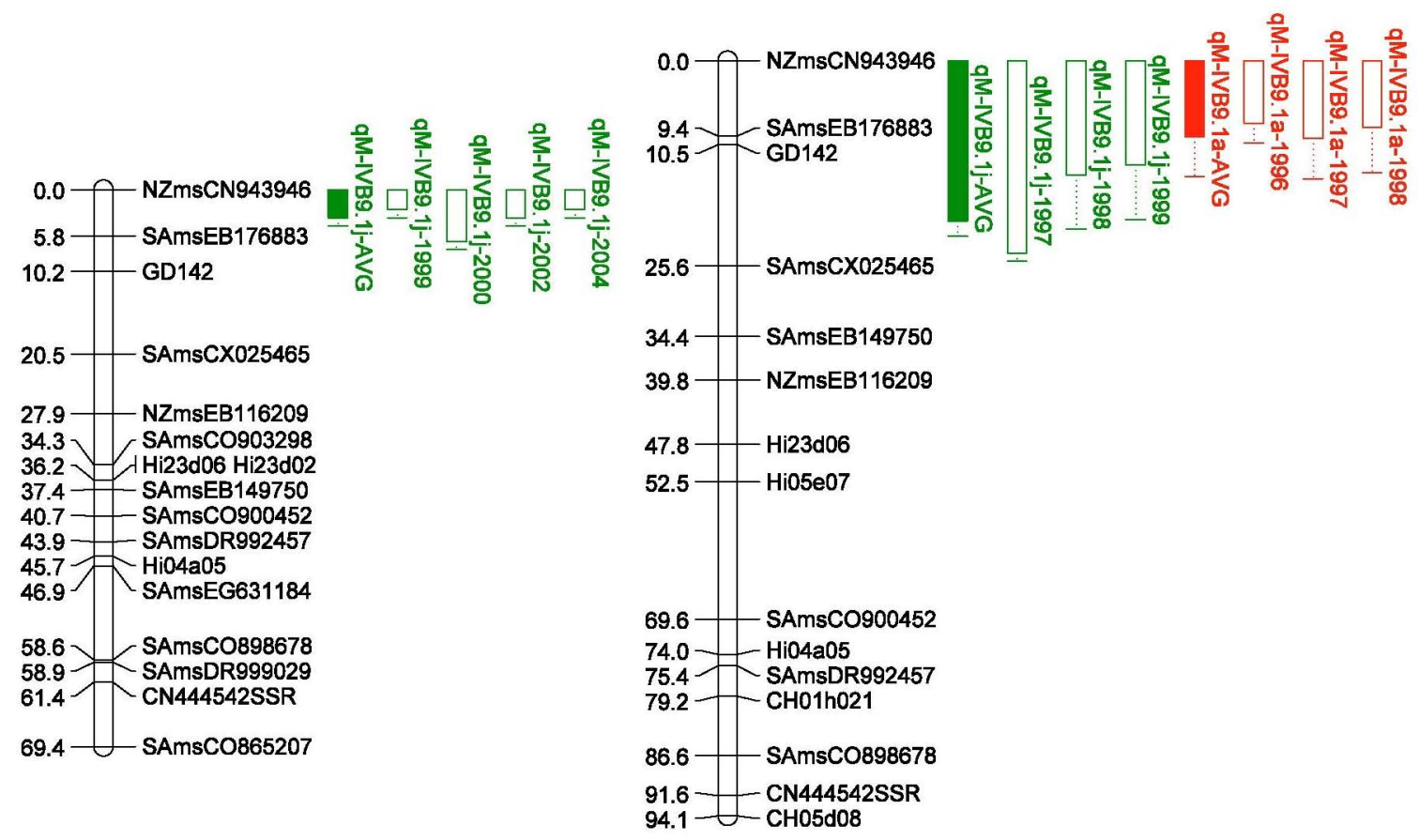

Figure 3: Position of the QTL for time of IVB detected on LG9 of the consensus 'Golden Delicious' $x$ 'Anna' (GDxAn) map and the 'Sharpe's Early' $x$ 'Anna' (SExAn) map. QTLs are represented by boxes where the length of the box corresponds to a $5 \%$ confidence interval and extended lines to a $10 \%$ confidence interval. Boxes representing average time of IVB are filled and boxes representing time of IVB for separate years are open. Boxes indicating QTL detected on juvenile trees are green and those indicating QTL detected on adult trees are red. 
Table 1 Pearson's correlation coefficients indicating phenotypic association $(P<0.0001)$ between different years for time of initial vegetative budbreak (IVB)

\begin{tabular}{|l|l|l|l|l|l|l|}
\hline \multirow{2}{*}{ Mapping population } & \multicolumn{5}{|l|}{ Association between different years of phenotypic trait assessment } \\
\cline { 2 - 7 } & Years 1 + 2 & Years 1 + 3 & Years 2 + 3 & Years 1 + 4 & Years 2+4 & Years 3 + 4 \\
\hline 'Golden Delicious' x 'Anna' & 0.68 & 0.69 & 0.68 & 0.70 & 0.78 & 0.67 \\
\hline 'Sharpe's Early'x 'Anna' (Adult trees) & 0.96 & 0.94 & 0.96 & & & \\
\hline 'Sharpe's Early'x 'Anna' (Young seedlings) & 0.81 & 0.80 & 0.90 & & & \\
\hline
\end{tabular}

${ }^{\mathrm{a}}$ Clonal trial 
Table 2 Summary of 116 new SSR markers, accession number, repeat motif, primers, resulting fragment sizes and genetic linkage map position

\begin{tabular}{|c|c|c|c|c|c|c|c|c|c|c|c|c|}
\hline \multirow[t]{4}{*}{ Marker } & \multirow[t]{4}{*}{$\begin{array}{l}\text { Repea } \\
t \\
\text { motif }\end{array}$} & \multirow[t]{4}{*}{ Forward primer } & \multirow[t]{4}{*}{ Reverse primer } & \multirow{2}{*}{\multicolumn{3}{|c|}{$\begin{array}{l}\text { Segregating alleles } \\
\text { scored }\end{array}$}} & \multirow{2}{*}{\multicolumn{2}{|c|}{$\begin{array}{l}\text { Genet } \\
\text { ic } \\
\text { linkag } \\
\text { e } \\
\text { maps } \\
\text { F1 } \\
\end{array}$}} & & & & \\
\hline & & & & & & & & & \multicolumn{4}{|c|}{ Parental } \\
\hline & & & & \multirow[t]{2}{*}{$\begin{array}{l}\text { 'An } \\
\text { na' }\end{array}$} & \multirow{2}{*}{$\begin{array}{c}\text { 'Gold } \\
\text { en } \\
\text { Delici } \\
\text { ous' }\end{array}$} & \multirow[t]{2}{*}{$\begin{array}{c}\text { 'Shar } \\
\text { pe's } \\
\text { Early' }\end{array}$} & \multirow{2}{*}{$\begin{array}{l}\text { 'Gold } \\
\text { en } \\
\text { Delici } \\
\text { ous' x } \\
\text { 'Anna } \\
\text {, }\end{array}$} & \multirow{2}{*}{$\begin{array}{l}\text { 'Shar } \\
\text { pe's } \\
\text { Early' } \\
\text { x } \\
\text { 'Anna }\end{array}$} & \multicolumn{2}{|c|}{$\begin{array}{l}\text { 'Golden } \\
\text { Delicious' x } \\
\text { 'Anna' }\end{array}$} & \multicolumn{2}{|c|}{$\begin{array}{l}\text { 'Sharpe's } \\
\text { Early'x } \\
\text { 'Anna' }\end{array}$} \\
\hline & & & & & & & & & $\begin{array}{l}\text { 'Gold } \\
\text { en } \\
\text { Delici } \\
\text { ous' }\end{array}$ & $\begin{array}{l}\text { 'An } \\
\text { na' }\end{array}$ & $\begin{array}{l}\text { 'Shar } \\
\text { pe's } \\
\text { Early' }\end{array}$ & $\begin{array}{l}\text { 'An } \\
\text { na' }\end{array}$ \\
\hline $\begin{array}{l}\text { SAmsCO86 } \\
5608\end{array}$ & $\begin{array}{l}\mathrm{TC} \\
(13)\end{array}$ & $\begin{array}{l}\text { CAACAAGTGTGCCT } \\
\text { CTGTGG }\end{array}$ & $\begin{array}{l}\text { AGCAAGCAACAGAT } \\
\text { CAAGCC }\end{array}$ & $\begin{array}{l}160- \\
168\end{array}$ & $\begin{array}{l}160- \\
164\end{array}$ & & 1 & & 1 & 1 & & \\
\hline $\begin{array}{l}\text { SAmsDR99 } \\
5748\end{array}$ & $\begin{array}{l}\text { TC } \\
(16.5)\end{array}$ & $\begin{array}{l}\text { TACACCAGCGCCAC } \\
\text { ACCG }\end{array}$ & $\begin{array}{l}\text { TGGCGAGCACGATG } \\
\text { AGCG }\end{array}$ & $\begin{array}{l}314- \\
334\end{array}$ & 334 & 334 & 1 & 1 & & 1 & & 1 \\
\hline $\begin{array}{l}\text { SAmsCN49 } \\
5924\end{array}$ & $\begin{array}{l}\mathrm{TC} \\
(14.5)\end{array}$ & $\begin{array}{l}\text { CTCTCAATGAGTCC } \\
\text { CCTGC }\end{array}$ & $\begin{array}{l}\text { AAACCCTGTGTTCAT } \\
\text { CTTCC }\end{array}$ & $\begin{array}{l}148- \\
175\end{array}$ & $\begin{array}{l}150- \\
173\end{array}$ & & 2 & & 2 & & & \\
\hline $\begin{array}{l}\text { SAmsCN58 } \\
1002\end{array}$ & $\begin{array}{l}\mathrm{TC} \\
(10)\end{array}$ & $\begin{array}{l}\text { TGGAGGGAAAGGA } \\
\text { GAAGCAG }\end{array}$ & $\begin{array}{l}\text { CTTGGAAGCTTTCTG } \\
\text { TCAGC }\end{array}$ & $\begin{array}{l}253- \\
267\end{array}$ & $\begin{array}{l}241- \\
253\end{array}$ & & 2 & & 2 & 2 & & \\
\hline $\begin{array}{l}\text { SAmsCO90 } \\
4847\end{array}$ & $\begin{array}{l}\text { GTT } \\
(11.3)\end{array}$ & $\begin{array}{l}\text { GTGGGTGTGGTTTTT } \\
\text { GATGG }\end{array}$ & $\begin{array}{l}\text { AGCTAAAGGAGAGC } \\
\text { TACACC }\end{array}$ & $\begin{array}{l}190- \\
193\end{array}$ & 182 & 193 & 2 & 2 & & 2 & & 2 \\
\hline $\begin{array}{l}\text { SAmsCN94 } \\
4528\end{array}$ & $\begin{array}{l}\text { GAC } \\
(11.7)\end{array}$ & $\begin{array}{l}\text { GACGACGGAAAGG } \\
\text { AAGACG }\end{array}$ & $\begin{array}{l}\text { ATTACGCTGTTGCAG } \\
\text { AGAGC }\end{array}$ & 204 & $\begin{array}{l}204- \\
214\end{array}$ & & 2 & & 2 & & & \\
\hline $\begin{array}{l}\text { SAmsEB10 } \\
6592\end{array}$ & $\begin{array}{l}\text { TCC } \\
(8.7)\end{array}$ & $\begin{array}{l}\text { CTTGGAAGCCCAAC } \\
\text { GAACC }\end{array}$ & $\begin{array}{l}\text { AGAGGAGCTTGTTGT } \\
\text { TGAGG }\end{array}$ & 236 & $\begin{array}{l}233- \\
236\end{array}$ & & 2 & & 2 & & & \\
\hline $\begin{array}{l}\text { SAmsEE66 } \\
3746\end{array}$ & $\begin{array}{l}\text { GA } \\
(15.5)\end{array}$ & $\begin{array}{l}\text { TGGCAATACCCGTT } \\
\text { CGACC }\end{array}$ & $\begin{array}{l}\text { CCATCAAATACAAG } \\
\text { CCCACC }\end{array}$ & $\begin{array}{l}305- \\
307\end{array}$ & $\begin{array}{l}305- \\
317\end{array}$ & $\begin{array}{l}315- \\
317\end{array}$ & 3 & 3 & 3 & 3 & 3 & \\
\hline $\begin{array}{l}\text { SAmsAU3 } \\
01301\end{array}$ & $\begin{array}{l}\text { CT } \\
(14.5)\end{array}$ & $\begin{array}{l}\text { GGCATAGCAATGCT } \\
\text { TGAAGG }\end{array}$ & $\begin{array}{l}\text { GAATAGCACAAAGG } \\
\text { AGGTTGC }\end{array}$ & $\begin{array}{l}228- \\
234\end{array}$ & $\begin{array}{l}223- \\
241\end{array}$ & 229 & 3 & & 3 & 3 & & \\
\hline $\begin{array}{l}\text { SAmsCN94 } \\
4444\end{array}$ & $\begin{array}{l}\text { AAG } \\
(8.7)\end{array}$ & $\begin{array}{l}\text { TAGTGCAAGTACTG } \\
\text { GGGCC }\end{array}$ & $\begin{array}{l}\text { CATCGATAGAATAG } \\
\text { GACGGC }\end{array}$ & $\begin{array}{l}371- \\
374\end{array}$ & $\begin{array}{l}371- \\
378\end{array}$ & $\begin{array}{l}374- \\
376\end{array}$ & 3 & 3 & 3 & 3 & 3 & 3 \\
\hline SAmsEB13 & GGA & TCTCCCTCACTCGAC & GTTGCAGGAAGGAG & $243-$ & 253 & 250 & & 4 & & & & 4 \\
\hline
\end{tabular}




\begin{tabular}{|c|c|c|c|c|c|c|c|c|c|c|c|c|c|}
\hline 2187 & $(8.3)$ & GTTG & TGTCG & 250 & & & & & & & & & \\
\hline $\begin{array}{l}\text { SAmsCV12 } \\
8959\end{array}$ & $\begin{array}{l}\mathrm{TC} \\
(11.5)\end{array}$ & $\begin{array}{l}\text { AAATAGTGTGGAAG } \\
\text { ACGCGG }\end{array}$ & $\begin{array}{l}\text { CAATATACTAATGA } \\
\text { GTCCTTCG }\end{array}$ & 240 & $\begin{array}{l}232- \\
242\end{array}$ & & 4 & & 4 & & & & \\
\hline $\begin{array}{l}\text { SAmsCN57 } \\
9721\end{array}$ & $\begin{array}{l}\text { CT } \\
(14)\end{array}$ & $\begin{array}{l}\text { GATCCAAATCTCAA } \\
\text { АСССТСC }\end{array}$ & $\begin{array}{l}\text { GTTGAAGACGTGGTT } \\
\text { GGGC }\end{array}$ & $\begin{array}{l}246- \\
259\end{array}$ & $\begin{array}{l}248- \\
259\end{array}$ & 259 & 4 & 4 & 4 & 4 & & 4 & \\
\hline $\begin{array}{l}\text { SAmsEB15 } \\
3928\end{array}$ & $\begin{array}{l}\text { CT } \\
(25)\end{array}$ & $\begin{array}{l}\text { CTCAAATCCCAGAA } \\
\text { GATTATCC }\end{array}$ & $\begin{array}{l}\text { GTCCTCGGAATCGTC } \\
\text { CTCC }\end{array}$ & $\begin{array}{l}348- \\
350\end{array}$ & $\begin{array}{l}350- \\
357\end{array}$ & $\begin{array}{l}350- \\
353\end{array}$ & 4 & 4 & 4 & 4 & 4 & 4 & \\
\hline $\begin{array}{l}\text { SAmsCO05 } \\
2033\end{array}$ & $\begin{array}{l}\text { CT } \\
(11.5)\end{array}$ & $\begin{array}{l}\text { TTGCCAATCCGCAT } \\
\text { TCGCC }\end{array}$ & $\begin{array}{l}\text { TGAGGTTCCCGCCCT } \\
\text { TGC }\end{array}$ & 118 & $\begin{array}{l}118- \\
196\end{array}$ & & 5 & & 5 & & & & \\
\hline $\begin{array}{l}\text { SAmsCO75 } \\
6306\end{array}$ & $\begin{array}{l}\text { AAA } \\
\mathrm{T} \\
(5.8)\end{array}$ & $\begin{array}{l}\text { GTAAATATCACCAC } \\
\text { CACCGC }\end{array}$ & $\begin{array}{l}\text { ACACAGAACGTCGT } \\
\text { ACATCG }\end{array}$ & $\begin{array}{l}180- \\
184\end{array}$ & 180 & $\begin{array}{l}180- \\
186\end{array}$ & 5 & 5 & & 5 & & 5 & \\
\hline $\begin{array}{l}\text { SAmsCO41 } \\
6051\end{array}$ & $\begin{array}{l}\mathrm{AG} \\
(16)\end{array}$ & $\begin{array}{l}\text { CCTCACTAAACGCA } \\
\text { TTGCAC }\end{array}$ & $\begin{array}{l}\text { CGGTACGATGAGGA } \\
\text { TCATCC }\end{array}$ & $\begin{array}{l}120- \\
133\end{array}$ & $\begin{array}{l}120- \\
130\end{array}$ & $\begin{array}{l}130- \\
133\end{array}$ & 5 & 5 & 5 & & 5 & & \\
\hline $\begin{array}{l}\text { SAmsCN92 } \\
2831\end{array}$ & $\begin{array}{l}\mathrm{TC} \\
(13)\end{array}$ & $\begin{array}{l}\text { TTTAGATTCGGAGA } \\
\text { GGATACG }\end{array}$ & $\begin{array}{l}\text { CTGCTTGGAATCCTC } \\
\text { GAGC }\end{array}$ & 293 & $\begin{array}{l}290- \\
293\end{array}$ & $\begin{array}{l}293- \\
295\end{array}$ & 5 & 5 & 5 & & 5 & & \\
\hline $\begin{array}{l}\text { SAmsCN88 } \\
7525\end{array}$ & $\begin{array}{l}\text { TTTA } \\
(7.8)\end{array}$ & $\begin{array}{l}\text { TAGTAGCTACACAC } \\
\text { TCTTTCC }\end{array}$ & $\begin{array}{l}\text { GCATTGCCTTGAGCT } \\
\text { CCAG }\end{array}$ & 207 & $\begin{array}{l}207- \\
214\end{array}$ & & 5 & & 5 & & & & \\
\hline $\begin{array}{l}\text { SAmsCN54 } \\
4835\end{array}$ & $\begin{array}{l}\mathrm{AG} \\
(17.5)\end{array}$ & $\begin{array}{l}\text { AGGAGAGCTTTCTG } \\
\text { CATTCC }\end{array}$ & $\begin{array}{l}\text { AGCGCTATCCCCAGC } \\
\text { TGC }\end{array}$ & $\begin{array}{l}301- \\
303\end{array}$ & $\begin{array}{l}303- \\
305\end{array}$ & $\begin{array}{l}301- \\
303\end{array}$ & 5 & & 5 & 5 & & & \\
\hline $\begin{array}{l}\text { SAmsCN44 } \\
4942\end{array}$ & $\begin{array}{l}\text { CT } \\
(16.5)\end{array}$ & $\begin{array}{l}\text { GCTCTCAAAGTCTC } \\
\text { TCCAGC }\end{array}$ & $\begin{array}{l}\text { TACGGACTCTCTTTG } \\
\text { GGGC }\end{array}$ & $\begin{array}{l}265- \\
273\end{array}$ & 275 & & 6 & & & 6 & & & \\
\hline $\begin{array}{l}\text { SAmsEG63 } \\
1303\end{array}$ & $\begin{array}{l}\text { AT } \\
(25)\end{array}$ & $\begin{array}{l}\text { GGCATGTGAATATG } \\
\text { GTGAGC }\end{array}$ & $\begin{array}{l}\text { CCAATCAATGTCTTG } \\
\text { CTTACC }\end{array}$ & $\begin{array}{l}330- \\
351\end{array}$ & 327 & & 6 & & & 6 & & & \\
\hline $\begin{array}{l}\text { SAmsEB12 } \\
7535\end{array}$ & $\begin{array}{l}\text { GA } \\
(30)\end{array}$ & $\begin{array}{l}\text { AACACACACACCAC } \\
\text { CATTCG }\end{array}$ & $\begin{array}{l}\text { TAGGAAGTCGACGT } \\
\text { AGTCG }\end{array}$ & $\begin{array}{l}326- \\
330\end{array}$ & $\begin{array}{l}322- \\
330\end{array}$ & 326 & 6 & 6 & 6 & 6 & & 6 & \\
\hline $\begin{array}{l}\text { SAmsCV65 } \\
7225\end{array}$ & $\begin{array}{l}\text { TAT } \\
(10.3)\end{array}$ & $\begin{array}{l}\text { TCCCTGTCATCGAA } \\
\text { TGATGC }\end{array}$ & $\begin{array}{l}\text { GCAAACCCAATCAG } \\
\text { AAGGAC }\end{array}$ & 193 & $\begin{array}{l}193- \\
198\end{array}$ & & 6 & & 6 & & & & \\
\hline $\begin{array}{l}\text { SAmsDT04 } \\
1144\end{array}$ & $\begin{array}{l}\mathrm{AG} \\
(15)\end{array}$ & $\begin{array}{l}\text { AAATGCTGCAGTGA } \\
\text { GGCCC }\end{array}$ & $\begin{array}{l}\text { GAATTCCATCTAAAC } \\
\text { GAGAGC }\end{array}$ & $\begin{array}{l}349- \\
351\end{array}$ & 349 & $\begin{array}{l}349- \\
360\end{array}$ & 6 & 6 & & 6 & 6 & 6 & \\
\hline $\begin{array}{l}\text { SAmsCN92 } \\
7330\end{array}$ & $\begin{array}{l}\mathrm{ACC} \\
(7.3)\end{array}$ & $\begin{array}{l}\text { TTAAACTGCCAAAT } \\
\text { TGCACGG }\end{array}$ & $\begin{array}{l}\text { GTTGGGTATTTGCAT } \\
\text { GGTGG }\end{array}$ & $\begin{array}{l}438- \\
443\end{array}$ & $\begin{array}{l}431- \\
438\end{array}$ & & 7 & & 7 & 7 & & & \\
\hline $\begin{array}{l}\text { SAmsCN90 } \\
3950\end{array}$ & $\begin{array}{l}\text { AGA } \\
(14.3)\end{array}$ & $\begin{array}{l}\text { TTTCCCTTTTGGCCA } \\
\text { GTGCA }\end{array}$ & $\begin{array}{l}\text { GTTTGGGCCTCGATG } \\
\text { ATGG }\end{array}$ & $\begin{array}{l}306- \\
319\end{array}$ & $\begin{array}{l}297- \\
319\end{array}$ & & 7 & & 7 & 7 & & & \\
\hline
\end{tabular}




\begin{tabular}{|c|c|c|c|c|c|c|c|c|c|c|c|c|c|}
\hline $\begin{array}{l}\mathrm{SAmsCO75} \\
6781\end{array}$ & $\begin{array}{l}\text { CT } \\
(19.5)\end{array}$ & $\begin{array}{l}\text { ATAAGTTTAGGCTC } \\
\text { ATCTGCC }\end{array}$ & $\begin{array}{l}\text { AAACCCATCCCACTT } \\
\text { AAGGC }\end{array}$ & $\begin{array}{l}355- \\
361\end{array}$ & $\begin{array}{l}333- \\
361\end{array}$ & $\begin{array}{l}346- \\
379\end{array}$ & 7 & 7 & & 7 & 7 & 7 & \\
\hline $\begin{array}{l}\text { SAmsCO90 } \\
1343\end{array}$ & $\begin{array}{l}(\mathrm{CT}) \\
15.5\end{array}$ & $\begin{array}{l}\text { CACCTCTTCCCTCAT } \\
\text { CAGTC }\end{array}$ & $\begin{array}{l}\text { CGACAAAGGAGACT } \\
\text { GAGAGG }\end{array}$ & $\begin{array}{l}208- \\
222\end{array}$ & 208 & $\begin{array}{l}210- \\
230\end{array}$ & 7 & 7 & & 7 & 7 & 7 & \\
\hline $\begin{array}{l}\text { SAmsCN48 } \\
8733\end{array}$ & $\begin{array}{l}\mathrm{TC} \\
(13)\end{array}$ & $\begin{array}{l}\text { CACAACCATTCCAC } \\
\text { CAAGTC }\end{array}$ & $\begin{array}{l}\text { CAGCCGGAGCAGTC } \\
\text { TACC }\end{array}$ & $\begin{array}{l}127- \\
131\end{array}$ & $\begin{array}{l}131- \\
142\end{array}$ & & 7 & & & 7 & & & \\
\hline $\begin{array}{l}\text { SAmsEB12 } \\
7208\end{array}$ & $\begin{array}{l}\mathrm{AG} \\
(14.5)\end{array}$ & $\begin{array}{l}\text { ATTCCTCTCAACCCC } \\
\text { TATCC }\end{array}$ & $\begin{array}{l}\text { CACAGTGCTGTTAAA } \\
\text { GCTGG }\end{array}$ & $\begin{array}{l}479- \\
491\end{array}$ & 491 & $\begin{array}{l}479- \\
491\end{array}$ & 7 & & & 7 & & & \\
\hline $\begin{array}{l}\text { SAmsAB16 } \\
2040\end{array}$ & $\begin{array}{l}\mathrm{TC} \\
(39.5)\end{array}$ & $\begin{array}{l}\text { GGAGTGCTATTAGC } \\
\text { TCСТCC }\end{array}$ & $\begin{array}{l}\text { TCCTTGAATCTCAAC } \\
\text { TCTAGG }\end{array}$ & 266 & & $\begin{array}{l}266- \\
272\end{array}$ & & 7 & & & 7 & & \\
\hline $\begin{array}{l}\text { SAmsCV88 } \\
3434\end{array}$ & $\begin{array}{l}\mathrm{TC} \\
(23)\end{array}$ & $\begin{array}{l}\text { CGAAACTGGTCGAA } \\
\text { GAACCT }\end{array}$ & $\begin{array}{l}\text { AAACTACACAGAGC } \\
\text { AAGATGG }\end{array}$ & $\begin{array}{l}331- \\
335\end{array}$ & $\begin{array}{l}350- \\
354\end{array}$ & & 8 & & 8 & 8 & & & \\
\hline $\begin{array}{l}\text { SAmsEB15 } \\
1277\end{array}$ & $\begin{array}{l}\mathrm{TC} \\
(29)\end{array}$ & $\begin{array}{l}\text { TCСТСААТСТСТСТС } \\
\text { AАТАСC }\end{array}$ & $\begin{array}{l}\text { GCGTTCTAGAGAGA } \\
\text { GAAAGG }\end{array}$ & $\begin{array}{l}179- \\
197\end{array}$ & $\begin{array}{l}197- \\
202\end{array}$ & $\begin{array}{l}202- \\
214\end{array}$ & 8 & 8 & 8 & 8 & 8 & & \\
\hline $\begin{array}{l}\text { SAmsCN89 } \\
1581\end{array}$ & $\begin{array}{l}\text { TCC } \\
(8)\end{array}$ & $\begin{array}{l}\text { CCAAAACTCCCACG } \\
\text { ACCGC }\end{array}$ & $\begin{array}{l}\text { CCAGAGCTTGTAGG } \\
\text { ACTCG }\end{array}$ & $\begin{array}{l}294- \\
297\end{array}$ & $\begin{array}{l}294- \\
\text { null }\end{array}$ & & 8 & & 8 & & & & \\
\hline $\begin{array}{l}\text { SAmsEB17 } \\
6883\end{array}$ & $\begin{array}{l}\text { TGCT } \\
(8.5)\end{array}$ & $\begin{array}{l}\text { AAAGCTGCTTGCTT } \\
\text { GATTGC }\end{array}$ & $\begin{array}{l}\text { ACCATCAGCTGGGTT } \\
\text { CTCG }\end{array}$ & $\begin{array}{l}330- \\
338\end{array}$ & 322 & $\begin{array}{l}322- \\
338\end{array}$ & 9 & 9 & & 9 & 9 & 9 & \\
\hline $\begin{array}{l}\mathrm{SAmsCX02} \\
5465\end{array}$ & $\begin{array}{l}\text { GAC } \\
(10.7)\end{array}$ & $\begin{array}{l}\text { TGCTAGAGCTGCGT } \\
\text { TCTCC }\end{array}$ & $\begin{array}{l}\text { TCGCAGACTGCTCGC } \\
\text { TGC }\end{array}$ & $\begin{array}{l}232- \\
238\end{array}$ & $\begin{array}{l}232- \\
238\end{array}$ & 232 & 9 & 9 & & & & 9 & \\
\hline $\begin{array}{l}\text { SAmsCO90 } \\
3298\end{array}$ & $\begin{array}{l}\mathrm{TC} \\
(14)\end{array}$ & $\begin{array}{l}\text { TTGAGAAGCAATGC } \\
\text { TGCCTC }\end{array}$ & $\begin{array}{l}\text { TGCCACAGTTGGAA } \\
\text { GGTGG }\end{array}$ & 344 & $\begin{array}{l}344- \\
350\end{array}$ & $\begin{array}{l}342- \\
344\end{array}$ & 9 & & 9 & & & & \\
\hline $\begin{array}{l}\text { SAmsEB14 } \\
9750\end{array}$ & $\begin{array}{l}\mathrm{TC} \\
(19) \\
\end{array}$ & $\begin{array}{l}\text { ATCAAGGTGTGAGT } \\
\text { GTGTGC }\end{array}$ & $\begin{array}{l}\text { AAGCTTGCATCTCTA } \\
\text { GGTCC }\end{array}$ & $\begin{array}{l}258- \\
263\end{array}$ & 255 & & 9 & & & 9 & & & \\
\hline $\begin{array}{l}\text { SAmsCO90 } \\
0452\end{array}$ & $\begin{array}{l}\text { GA } \\
(12.5)\end{array}$ & $\begin{array}{l}\text { CAAGGCATCTCCCT } \\
\text { CATTGG }\end{array}$ & $\begin{array}{l}\text { TACTACAGTTCCGAT } \\
\text { CAAAGC }\end{array}$ & $\begin{array}{l}291- \\
314\end{array}$ & $\begin{array}{l}293- \\
295\end{array}$ & $\begin{array}{l}311- \\
314\end{array}$ & 9 & 9 & 9 & 9 & 9 & 9 & \\
\hline $\begin{array}{l}\text { SAmsEG63 } \\
1184 \\
\end{array}$ & $\begin{array}{l}\text { GA } \\
(10) \\
\end{array}$ & $\begin{array}{l}\text { CTTATGGACCCTGC } \\
\text { AAATGG }\end{array}$ & $\begin{array}{l}\text { AGACTCTGTACATAC } \\
\text { ATCTCC }\end{array}$ & $\begin{array}{l}447- \\
464 \\
\end{array}$ & 447 & & 9 & & & 9 & & & \\
\hline $\begin{array}{l}\text { SAmsDR99 } \\
2457\end{array}$ & $\begin{array}{l}\mathrm{AGC} \\
(13.7)\end{array}$ & $\begin{array}{l}\text { TCTCCAAGTGGACG } \\
\text { AATCAG }\end{array}$ & $\begin{array}{l}\text { TCCTCAGTGAAGAC } \\
\text { AAACCC }\end{array}$ & $\begin{array}{l}360- \\
370\end{array}$ & $\begin{array}{l}356- \\
368\end{array}$ & $\begin{array}{l}360- \\
365\end{array}$ & 9 & 9 & 9 & 9 & 9 & 9 & \\
\hline $\begin{array}{l}\text { SAmsCO89 } \\
8678\end{array}$ & $\begin{array}{l}\text { CT } \\
(16)\end{array}$ & $\begin{array}{l}\text { CCCAAGTGCACCAC } \\
\text { ATACAG }\end{array}$ & $\begin{array}{l}\text { AGCTTCTGGCAGCA } \\
\text { AGTGC }\end{array}$ & 242 & $\begin{array}{l}238- \\
244\end{array}$ & $\begin{array}{l}238- \\
242\end{array}$ & 9 & 9 & 9 & & 9 & & \\
\hline $\begin{array}{l}\text { SAmsDR99 } \\
9029\end{array}$ & $\begin{array}{l}\mathrm{TC} \\
(14)\end{array}$ & $\begin{array}{l}\text { CGCCCTCACTCATTC } \\
\text { AGTC }\end{array}$ & $\begin{array}{l}\text { TCAACATGAACTTCA } \\
\text { GTCGC }\end{array}$ & 440 & $440-$ & 440 & 9 & & 9 & & & & \\
\hline
\end{tabular}




\begin{tabular}{|c|c|c|c|c|c|c|c|c|c|c|c|c|}
\hline & & & & & 443 & & & & & & & \\
\hline $\begin{array}{l}\text { SAmsCO86 } \\
5207\end{array}$ & $\begin{array}{l}\text { GA } \\
(13.5)\end{array}$ & $\begin{array}{l}\text { TGCACCAAATAAGC } \\
\text { CGATCC }\end{array}$ & $\begin{array}{l}\text { CAAGAAGTGCAACC } \\
\text { AGTCGA }\end{array}$ & $\begin{array}{l}134- \\
138\end{array}$ & 120 & & 9 & & & & & \\
\hline $\begin{array}{l}\text { SAmsCN44 } \\
4550\end{array}$ & $\begin{array}{l}\text { TGG } \\
\text { AT (5) }\end{array}$ & $\begin{array}{l}\text { AGCATCAAGCCAAT } \\
\text { CTTTAAGC }\end{array}$ & $\begin{array}{l}\text { GTATGCTCTTCTTCT } \\
\text { TCATGG }\end{array}$ & $\begin{array}{l}346- \\
351\end{array}$ & 341 & 341 & & 10 & & & & 10 \\
\hline $\begin{array}{l}\text { SAmsEB13 } \\
\text { 2791a }\end{array}$ & \multirow[t]{2}{*}{$\begin{array}{l}\mathrm{CT} \\
(17.5)\end{array}$} & \multirow[t]{2}{*}{$\begin{array}{l}\text { CACTACAGAACTCC } \\
\text { TCATCC }\end{array}$} & \multirow[t]{2}{*}{$\begin{array}{l}\text { GTGGGATGGAACCG } \\
\text { AAACC }\end{array}$} & 312 & $\begin{array}{l}312- \\
316\end{array}$ & & 10 & & 10 & & & \\
\hline $\begin{array}{l}\text { SAmsEB13 } \\
2791 b\end{array}$ & & & & $\begin{array}{l}344- \\
350\end{array}$ & $\begin{array}{l}340- \\
350\end{array}$ & $\begin{array}{l}344- \\
350\end{array}$ & 10 & & 10 & 10 & & \\
\hline $\begin{array}{l}\text { SAmsCO75 } \\
5814\end{array}$ & $\begin{array}{l}\text { CT } \\
(21)\end{array}$ & $\begin{array}{l}\text { AACATCAAGACAGA } \\
\text { GAAGAGC }\end{array}$ & $\begin{array}{l}\text { CGTCTTCTTCACAAA } \\
\text { CTCCG }\end{array}$ & 263 & $\begin{array}{l}257- \\
263\end{array}$ & & 10 & & 10 & & & \\
\hline $\begin{array}{l}\text { SAmsCN99 } \\
6777\end{array}$ & $\begin{array}{l}\text { CACC } \\
\mathrm{T}(5)\end{array}$ & $\begin{array}{l}\text { TGACAACTATGATC } \\
\text { GAAGTGG }\end{array}$ & $\begin{array}{l}\text { TTT } \\
\text { CATATCACATGACGT } \\
\text { GGC }\end{array}$ & $\begin{array}{l}270- \\
275\end{array}$ & 275 & $\begin{array}{l}266- \\
275\end{array}$ & 10 & 10 & & 10 & 10 & 10 \\
\hline $\begin{array}{l}\text { SAmsCN86 } \\
5016\end{array}$ & $\begin{array}{l}\text { CAT } \\
(14)\end{array}$ & $\begin{array}{l}\text { TTCTTCACACCCTTC } \\
\text { AATCC }\end{array}$ & $\begin{array}{l}\text { AAAGCGCCTGCGAT } \\
\text { TGCG }\end{array}$ & $\begin{array}{l}340- \\
345\end{array}$ & $\begin{array}{l}334- \\
340\end{array}$ & $\begin{array}{l}340- \\
345\end{array}$ & 10 & 10 & & 10 & & \\
\hline $\begin{array}{l}\text { SAmsU501 } \\
87\end{array}$ & $\begin{array}{l}\mathrm{GA} \\
(17.5)\end{array}$ & $\begin{array}{l}\text { ACCTGAGAGAGCTC } \\
\text { CAAACG }\end{array}$ & $\begin{array}{l}\text { GTGCGCCACGTCAA } \\
\text { ATACG }\end{array}$ & $\begin{array}{l}160- \\
\text { null }\end{array}$ & $\begin{array}{l}149- \\
162\end{array}$ & $\begin{array}{l}149- \\
162\end{array}$ & 10 & 10 & 10 & 10 & 10 & 10 \\
\hline $\begin{array}{l}\text { SAmsEB15 } \\
3442\end{array}$ & $\begin{array}{l}\text { CT } \\
(23.5)\end{array}$ & $\begin{array}{l}\text { GGTTCACAAGGCCA } \\
\text { ACTTTG }\end{array}$ & $\begin{array}{l}\text { ATGGTTCGATCGGTT } \\
\text { TAATGC }\end{array}$ & $\begin{array}{l}366- \\
373\end{array}$ & 373 & $\begin{array}{l}371- \\
373\end{array}$ & 10 & 10 & & 10 & & 10 \\
\hline $\begin{array}{l}\text { SAmsDR99 } \\
0381\end{array}$ & $\begin{array}{l}\text { TCT } \\
(9.7)\end{array}$ & $\begin{array}{l}\text { AAACACTACTGTGC } \\
\text { TGGTGG }\end{array}$ & $\begin{array}{l}\text { AGTCCACTTACTACT } \\
\text { CCTCC }\end{array}$ & $\begin{array}{l}287- \\
300\end{array}$ & 300 & $\begin{array}{l}294- \\
300\end{array}$ & 10 & 10 & & 10 & 10 & 10 \\
\hline $\begin{array}{l}\text { SAmsDR99 } \\
6792\end{array}$ & $\begin{array}{l}\text { CT } \\
(15)\end{array}$ & $\begin{array}{l}\text { AGGCTTCCTTCCTTT } \\
\text { CTTCC }\end{array}$ & $\begin{array}{l}\text { GGACCATTTGTGGTG } \\
\text { GAGC }\end{array}$ & $\begin{array}{l}378- \\
399\end{array}$ & 397 & $\begin{array}{l}388- \\
396\end{array}$ & 10 & 10 & & 10 & 10 & 10 \\
\hline $\begin{array}{l}\text { SAmsCO75 } \\
1676\end{array}$ & $\begin{array}{l}\mathrm{TC} \\
(15)\end{array}$ & $\begin{array}{l}\text { TGTGGCTCTGGATG } \\
\text { GTTCC }\end{array}$ & $\begin{array}{l}\text { TACCAGTCCATCCGT } \\
\text { ATAGC }\end{array}$ & 233 & 218 & $\begin{array}{l}218- \\
228\end{array}$ & & 10 & & & 10 & 10 \\
\hline $\begin{array}{l}\text { SAmsCN87 } \\
9152\end{array}$ & $\begin{array}{l}\text { ATC } \\
(7.3)\end{array}$ & $\begin{array}{l}\text { CGTTGGAGATGATC } \\
\text { AGTACG }\end{array}$ & $\begin{array}{l}\text { ACCTACAATAGTAGT } \\
\text { GGAGAC }\end{array}$ & $\begin{array}{l}256- \\
\text { null }\end{array}$ & $\begin{array}{l}243- \\
256\end{array}$ & & 10 & & & 10 & & \\
\hline $\begin{array}{l}\text { SAmsCN48 } \\
9062\end{array}$ & $\begin{array}{l}\text { GA } \\
(13)\end{array}$ & $\begin{array}{l}\text { ACAACTTGGTTACG } \\
\text { CGACAC }\end{array}$ & $\begin{array}{l}\text { GAACAGATTAGGGT } \\
\text { CGCTGG }\end{array}$ & $\begin{array}{l}296- \\
300\end{array}$ & $\begin{array}{l}284- \\
314\end{array}$ & $\begin{array}{l}284- \\
296\end{array}$ & 10 & 10 & & 10 & 10 & 10 \\
\hline $\begin{array}{l}\text { SAmsDR99 } \\
4153\end{array}$ & $\begin{array}{l}\mathrm{AG} \\
(14.5)\end{array}$ & $\begin{array}{l}\text { CACGAGGCGAAACC } \\
\text { GATC }\end{array}$ & $\begin{array}{l}\text { AGGTCCTCAGAACCT } \\
\text { GAGC }\end{array}$ & $\begin{array}{l}465- \\
472\end{array}$ & $\begin{array}{l}463- \\
465\end{array}$ & $\begin{array}{l}465- \\
472\end{array}$ & 10 & & 10 & 10 & & \\
\hline $\begin{array}{l}\text { SAmsEB14 } \\
9851\end{array}$ & $\begin{array}{l}\text { AGA } \\
(10.3)\end{array}$ & $\begin{array}{l}\text { GAA CAG AGG GAA } \\
\text { GCA GAC G }\end{array}$ & $\begin{array}{l}\text { AGA AGT GGC AAC } \\
\text { CAT GTT GC }\end{array}$ & $\begin{array}{l}187- \\
190\end{array}$ & $\begin{array}{l}190- \\
202\end{array}$ & $\begin{array}{l}187- \\
202\end{array}$ & 10 & 10 & & 10 & 10 & 10 \\
\hline
\end{tabular}




\begin{tabular}{|c|c|c|c|c|c|c|c|c|c|c|c|c|}
\hline $\begin{array}{l}\text { SAmsCN87 } \\
7882\end{array}$ & $\begin{array}{l}\text { CTAG } \\
\mathrm{T} \\
(6.8)\end{array}$ & $\begin{array}{l}\text { AACTTGCTGAGAGA } \\
\text { GTAATGG }\end{array}$ & $\begin{array}{l}\text { CAACCAAAGGGCCT } \\
\text { GAAGC }\end{array}$ & 485 & $\begin{array}{l}495- \\
500\end{array}$ & $\begin{array}{l}485- \\
500\end{array}$ & 11 & 11 & 11 & & 11 & \\
\hline $\begin{array}{l}\text { SAmsEB12 } \\
8431\end{array}$ & $\begin{array}{l}\text { TAA } \\
(17)\end{array}$ & $\begin{array}{l}\text { ACGTAGTGATACCG } \\
\text { GATTCG }\end{array}$ & $\begin{array}{l}\text { AGAGCTAGCTAGAG } \\
\text { ATATTCC }\end{array}$ & 335 & $\begin{array}{l}342- \\
\text { null }\end{array}$ & $\begin{array}{l}322- \\
342\end{array}$ & & 11 & & & 11 & \\
\hline $\begin{array}{l}\text { SAmsDR99 } \\
4274\end{array}$ & $\begin{array}{l}\mathrm{ACC} \\
(12.3)\end{array}$ & $\begin{array}{l}\text { CCACCCACAAAACA } \\
\text { TACACC }\end{array}$ & $\begin{array}{l}\text { TGCTGTTGTTGGTGA } \\
\text { TGTGG }\end{array}$ & 228 & $\begin{array}{l}221- \\
228\end{array}$ & & 11 & & 11 & & & \\
\hline $\begin{array}{l}\text { SAmsDR99 } \\
3043\end{array}$ & $\begin{array}{l}\mathrm{TC} \\
(13.5)\end{array}$ & $\begin{array}{l}\text { CACGAGGGTAAGCT } \\
\text { CCCC }\end{array}$ & $\begin{array}{l}\text { TTGGGGTTATTGCTC } \\
\text { TGACG }\end{array}$ & $\begin{array}{l}298- \\
314\end{array}$ & $\begin{array}{l}279- \\
304\end{array}$ & $\begin{array}{l}293- \\
307\end{array}$ & 11 & 11 & 11 & 11 & 11 & 11 \\
\hline $\begin{array}{l}\text { SAmsCN94 } \\
2929\end{array}$ & $\begin{array}{l}\text { GTTT } \\
(5)\end{array}$ & $\begin{array}{l}\text { ACGCTAGGAGAGAG } \\
\text { GAACG }\end{array}$ & $\begin{array}{l}\text { GAGCATTCCGTATTA } \\
\text { AATCCG }\end{array}$ & $\begin{array}{l}519- \\
524\end{array}$ & $\begin{array}{l}524- \\
529\end{array}$ & 524 & 11 & 11 & 11 & 11 & & 11 \\
\hline $\begin{array}{l}\text { SAmsCN58 } \\
0620\end{array}$ & $\begin{array}{l}\text { CGG } \\
(7)\end{array}$ & $\begin{array}{l}\text { TGCGGTCAACGATG } \\
\text { TCTTCG }\end{array}$ & $\begin{array}{l}\text { AAGGTACAAGCCCG } \\
\text { CAAAGG }\end{array}$ & 380 & $\begin{array}{l}377- \\
380\end{array}$ & & 12 & & 12 & & & \\
\hline $\begin{array}{l}\text { SAmsEB13 } \\
9609\end{array}$ & $\begin{array}{l}\mathrm{AG} \\
(32)\end{array}$ & $\begin{array}{l}\text { ACCATATACATCTC } \\
\text { TCTCTGC }\end{array}$ & $\begin{array}{l}\text { TTCAGAAGCTGTTGT } \\
\text { TGTTGG }\end{array}$ & $\begin{array}{l}322- \\
334\end{array}$ & $\begin{array}{l}313- \\
358\end{array}$ & $\begin{array}{l}340- \\
358\end{array}$ & 12 & 12 & 12 & 12 & 12 & 12 \\
\hline $\begin{array}{l}\text { SAmsCN94 } \\
3613\end{array}$ & $\begin{array}{l}\text { CTT } \\
(7.3)\end{array}$ & $\begin{array}{l}\text { TAGCAGAAACCAGC } \\
\text { AGATGG }\end{array}$ & $\begin{array}{l}\text { GAAGGACCCGAATT } \\
\text { GGAGC }\end{array}$ & $\begin{array}{l}165- \\
174\end{array}$ & 174 & & 12 & & & 12 & & \\
\hline $\begin{array}{l}\text { SAmsDR99 } \\
5002\end{array}$ & $\begin{array}{l}\text { GAT } \\
(8)\end{array}$ & $\begin{array}{l}\text { ATCTGATGGTGCAT } \\
\text { CGGTAG }\end{array}$ & $\begin{array}{l}\text { TTAGGGTCTTCTTGT } \\
\text { CACGC }\end{array}$ & $\begin{array}{l}329- \\
332\end{array}$ & 332 & 332 & 12 & 12 & & 12 & & 12 \\
\hline $\begin{array}{l}\text { SAmsCN49 } \\
2206\end{array}$ & $\begin{array}{l}\text { TTG } \\
(10.7)\end{array}$ & $\begin{array}{l}\text { ACATACTGGAGTCT } \\
\text { GCGAGC }\end{array}$ & $\begin{array}{l}\text { CAATACGCTAGTGA } \\
\text { AGACGC }\end{array}$ & 398 & $\begin{array}{l}398- \\
471\end{array}$ & & 13 & & 13 & & & \\
\hline $\begin{array}{l}\text { SAmsCO05 } \\
2555\end{array}$ & $\begin{array}{l}\text { AT } \\
(12.5)\end{array}$ & $\begin{array}{l}\text { GAAGTTCTCATCAA } \\
\text { GTCTTGC }\end{array}$ & $\begin{array}{l}\text { GCTTCTGCACAATGG } \\
\text { CTGG }\end{array}$ & $\begin{array}{l}232- \\
234\end{array}$ & 236 & 232 & 13 & 13 & & 13 & & 13 \\
\hline $\begin{array}{l}\text { SAmsCN44 } \\
5562\end{array}$ & $\begin{array}{l}\mathrm{TC} \\
(23.5)\end{array}$ & $\begin{array}{l}\text { CACAAACCAACCGT } \\
\text { CTAACC }\end{array}$ & $\begin{array}{l}\text { GCTCTTGATCATAGG } \\
\text { CGTGG }\end{array}$ & $\begin{array}{l}139- \\
154\end{array}$ & $\begin{array}{l}150- \\
154\end{array}$ & & 13 & & & 13 & & \\
\hline $\begin{array}{l}\text { SAmsCO41 } \\
6477\end{array}$ & $\begin{array}{l}\mathrm{CT}(14 \\
)\end{array}$ & $\begin{array}{l}\text { CCACACAACACAAA } \\
\text { CCAACC }\end{array}$ & $\begin{array}{l}\text { GAGGCATTGATCCTC } \\
\text { ATCGT }\end{array}$ & 218 & $\begin{array}{l}218- \\
224\end{array}$ & & 13 & & 13 & & & \\
\hline $\begin{array}{l}\text { SAmsCO06 } \\
8842\end{array}$ & $\begin{array}{l}\mathrm{TC} \\
(22)\end{array}$ & $\begin{array}{l}\text { TGGTTGGAGATGTT } \\
\text { CCATGG }\end{array}$ & $\begin{array}{l}\text { ACCAGCTAGATTATC } \\
\text { TTCTGC }\end{array}$ & $\begin{array}{l}455- \\
\text { null }\end{array}$ & $\begin{array}{l}401- \\
447\end{array}$ & & 13 & & 13 & 13 & & \\
\hline $\begin{array}{l}\text { SAmsEB15 } \\
4452\end{array}$ & $\begin{array}{l}\text { GATC } \\
\text { (5) }\end{array}$ & $\begin{array}{l}\text { CACTCAACTCACGT } \\
\text { TTCTCC }\end{array}$ & $\begin{array}{l}\text { AGGCAGAAGGCAGA } \\
\text { AGAGG }\end{array}$ & $\begin{array}{l}169- \\
174\end{array}$ & $\begin{array}{l}174- \\
184\end{array}$ & $\begin{array}{l}174- \\
181\end{array}$ & 14 & 14 & 14 & 14 & 14 & 14 \\
\hline $\begin{array}{l}\text { SAmsCN88 } \\
0881\end{array}$ & $\begin{array}{l}\text { CCA } \\
(10)\end{array}$ & $\begin{array}{l}\text { ATAGCTCATACCGC } \\
\text { TTCTCC }\end{array}$ & $\begin{array}{l}\text { GTGACGAAAACCAA } \\
\text { GAACCC }\end{array}$ & $\begin{array}{l}427- \\
429\end{array}$ & $\begin{array}{l}406- \\
408\end{array}$ & $\begin{array}{l}406- \\
427\end{array}$ & 14 & 14 & 14 & 14 & 14 & 14 \\
\hline $\begin{array}{l}\text { SAmsCN49 } \\
1038\end{array}$ & $\begin{array}{l}\text { TC } \\
(19)\end{array}$ & $\begin{array}{l}\text { GCTCTGTCTCGTTGA } \\
\text { TCGG }\end{array}$ & $\begin{array}{l}\text { AGCTGCTTCACCCTC } \\
\text { TTGC }\end{array}$ & $\begin{array}{l}498- \\
510\end{array}$ & 510 & & 14 & & & 14 & & \\
\hline
\end{tabular}




\begin{tabular}{|c|c|c|c|c|c|c|c|c|c|c|c|c|}
\hline $\begin{array}{l}\text { SAmsCN58 } \\
1649 \mathrm{a}\end{array}$ & $\begin{array}{l}\text { CAT } \\
(13.3)\end{array}$ & $\begin{array}{l}\text { AGCCCTGATCTTCCT } \\
\text { CTAGC }\end{array}$ & $\begin{array}{l}\text { GACAATCTTCTGAAA } \\
\text { GTCTGG }\end{array}$ & $\begin{array}{l}343- \\
351\end{array}$ & $\begin{array}{l}351- \\
354\end{array}$ & & 14 & & 14 & 14 & & \\
\hline $\begin{array}{l}\text { SAmsEB14 } \\
4379\end{array}$ & $\begin{array}{l}\text { GGC } \\
\text { GGT } \\
(4.5) \\
\end{array}$ & $\begin{array}{l}\text { AGCTGATGGCCAGA } \\
\text { ACTGC }\end{array}$ & $\begin{array}{l}\text { GAGGGTCCAAGTTA } \\
\text { CAAAGG }\end{array}$ & 418 & $\begin{array}{l}412- \\
418\end{array}$ & $\begin{array}{l}412- \\
418\end{array}$ & 14 & 14 & 14 & & 14 & \\
\hline $\begin{array}{l}\text { SAmsCN49 } \\
4928\end{array}$ & $\begin{array}{l}\text { ATC } \\
(14)\end{array}$ & $\begin{array}{l}\text { AATTATATCCGTCC } \\
\text { GACTCCA }\end{array}$ & $\begin{array}{l}\text { TTACTGCTACCTGAT } \\
\text { GATCC }\end{array}$ & 226 & $\begin{array}{l}209- \\
219\end{array}$ & $\begin{array}{l}209- \\
215\end{array}$ & 14 & 14 & 14 & 14 & 14 & 14 \\
\hline $\begin{array}{l}\text { SAmsEB11 } \\
4233\end{array}$ & $\begin{array}{l}\text { GA } \\
(11.5)\end{array}$ & $\begin{array}{l}\text { GCATCCGCCATTGT } \\
\text { TGTCG }\end{array}$ & $\begin{array}{l}\text { TGGATTGAGACTGA } \\
\text { GAGAGG }\end{array}$ & $\begin{array}{l}221- \\
227\end{array}$ & $\begin{array}{l}217- \\
223\end{array}$ & $\begin{array}{l}227- \\
231\end{array}$ & 14 & 14 & 14 & 14 & 14 & 14 \\
\hline $\begin{array}{l}\text { SAmsEB14 } \\
7331\end{array}$ & $\begin{array}{l}\text { CT } \\
(26)\end{array}$ & $\begin{array}{l}\text { CCTAACTCTGACTC } \\
\text { AGTTGC }\end{array}$ & $\begin{array}{l}\text { AGTGTCGTCTGGAGC } \\
\text { TTCC }\end{array}$ & 257 & $\begin{array}{l}261- \\
266\end{array}$ & $\begin{array}{l}264- \\
266\end{array}$ & 15 & 15 & 15 & & 15 & \\
\hline $\begin{array}{l}\text { SAmsCN94 } \\
4665\end{array}$ & $\begin{array}{l}\text { TATG } \\
(10.8)\end{array}$ & $\begin{array}{l}\text { GTCTCTGCTTGCTTA } \\
\text { ATTCAG }\end{array}$ & $\begin{array}{l}\text { AGGCCAATCCTGACT } \\
\text { ATAG }\end{array}$ & 320 & $\begin{array}{l}224- \\
320\end{array}$ & & 15 & & 15 & & & \\
\hline $\begin{array}{l}\text { SAmsCN49 } \\
0349\end{array}$ & $\begin{array}{l}\text { AGG } \\
(8.7)\end{array}$ & $\begin{array}{l}\text { GTACTATCAGCAGA } \\
\text { AACTGG }\end{array}$ & $\begin{array}{l}\text { GATTTGAGCACAAC } \\
\text { ATACGG }\end{array}$ & 200 & $\begin{array}{l}200- \\
206\end{array}$ & 200 & 15 & & 15 & & & \\
\hline $\begin{array}{l}\mathrm{SAmsCN} 44 \\
5253\end{array}$ & $\begin{array}{l}\text { CTG } \\
(8)\end{array}$ & $\begin{array}{l}\text { TGCAAGAATCATCC } \\
\text { ACTTCC }\end{array}$ & $\begin{array}{l}\text { TTGGACCTGTGAGG } \\
\text { ACTCC }\end{array}$ & $\begin{array}{l}478- \\
494\end{array}$ & 491 & & 15 & & & 15 & & \\
\hline $\begin{array}{l}\text { SAmsCO90 } \\
0034\end{array}$ & $\begin{array}{l}\text { AAG } \\
(10.3)\end{array}$ & $\begin{array}{l}\text { AAAGTCCGTTTTGG } \\
\text { GCTGAG }\end{array}$ & $\begin{array}{l}\text { GCTCTCTGCTGCCAT } \\
\text { TTCC }\end{array}$ & $\begin{array}{l}361- \\
367\end{array}$ & $\begin{array}{l}353- \\
367\end{array}$ & $\begin{array}{l}361- \\
367\end{array}$ & 15 & & 15 & 15 & & \\
\hline $\begin{array}{l}\text { SAmsCO05 } \\
1709\end{array}$ & $\begin{array}{l}\text { CTCA } \\
\text { AG } \\
(3.5)\end{array}$ & $\begin{array}{l}\text { CTGTGCCGTCATCT } \\
\text { ATATGC }\end{array}$ & $\begin{array}{l}\text { AACCAAAGAGGGAA } \\
\text { GAGACG }\end{array}$ & 193 & $\begin{array}{l}193- \\
200\end{array}$ & & 15 & & 15 & & & \\
\hline $\begin{array}{l}\text { SAmsCN58 } \\
0637\end{array}$ & $\begin{array}{l}\mathrm{TC}(16 \\
.5)\end{array}$ & $\begin{array}{l}\text { ACAACAGCTGACGA } \\
\text { ACAAGC }\end{array}$ & $\begin{array}{l}\text { CTACTCGTCGAAGTA } \\
\text { CGCC }\end{array}$ & 418 & $\begin{array}{l}406- \\
418\end{array}$ & & 15 & & 15 & & & \\
\hline $\begin{array}{l}\text { SAmsCO41 } \\
5353\end{array}$ & $\begin{array}{l}\mathrm{AG}(1 \\
4)\end{array}$ & $\begin{array}{l}\text { ATGAACAGTCACAG } \\
\text { ACTATGC }\end{array}$ & $\begin{array}{l}\text { AACGAAGCAAAGGA } \\
\text { AGACGG }\end{array}$ & $\begin{array}{l}329- \\
333\end{array}$ & $\begin{array}{l}329- \\
333\end{array}$ & $\begin{array}{l}329- \\
333\end{array}$ & 15 & 15 & & & & \\
\hline $\begin{array}{l}\text { SAmsCN94 } \\
7446\end{array}$ & $\begin{array}{l}\mathrm{CTT}(8 \\
.3)\end{array}$ & $\begin{array}{l}\text { CCGTTACAGCTATC } \\
\text { CAAACC }\end{array}$ & $\begin{array}{l}\text { ATAATGGCCATTCTG } \\
\text { TTCAGC }\end{array}$ & $\begin{array}{l}178- \\
181\end{array}$ & $\begin{array}{l}181- \\
184\end{array}$ & $\begin{array}{l}181- \\
187\end{array}$ & 15 & 15 & 15 & 15 & 15 & 15 \\
\hline $\begin{array}{l}\text { SAmsEB12 } \\
6773\end{array}$ & $\begin{array}{l}\mathrm{CT}(23 \\
.5)\end{array}$ & $\begin{array}{l}\text { GTTTGTGTTTGAAC } \\
\text { AACGACC }\end{array}$ & $\begin{array}{l}\text { GTGGTTGTTGAGGTC } \\
\text { GTGG }\end{array}$ & $\begin{array}{l}447- \\
453\end{array}$ & $\begin{array}{l}441- \\
447\end{array}$ & $\begin{array}{l}455- \\
469\end{array}$ & 15 & 15 & 15 & 15 & 15 & 15 \\
\hline $\begin{array}{l}\text { SAmsDT04 } \\
2298\end{array}$ & GT(12 & $\begin{array}{l}\text { AGCATGTTGTGGGA } \\
\text { AGCCC }\end{array}$ & $\begin{array}{l}\text { GCATACTCTCATACA } \\
\text { AGTCCG }\end{array}$ & $\begin{array}{l}227- \\
229\end{array}$ & $\begin{array}{l}225- \\
227\end{array}$ & $\begin{array}{l}227- \\
229\end{array}$ & 15 & & 15 & 15 & & \\
\hline $\begin{array}{l}\text { SAmsDR99 } \\
7862\end{array}$ & $\begin{array}{l}\text { TCTG } \\
(7.8)\end{array}$ & $\begin{array}{l}\text { CACAATCATATTCC } \\
\text { CGCACG }\end{array}$ & $\begin{array}{l}\text { TTCTTCTCCGATGAG } \\
\text { CAAGC }\end{array}$ & $\begin{array}{l}275- \\
280\end{array}$ & $\begin{array}{l}275- \\
283\end{array}$ & 275 & 15 & 15 & 15 & 15 & & 15 \\
\hline
\end{tabular}




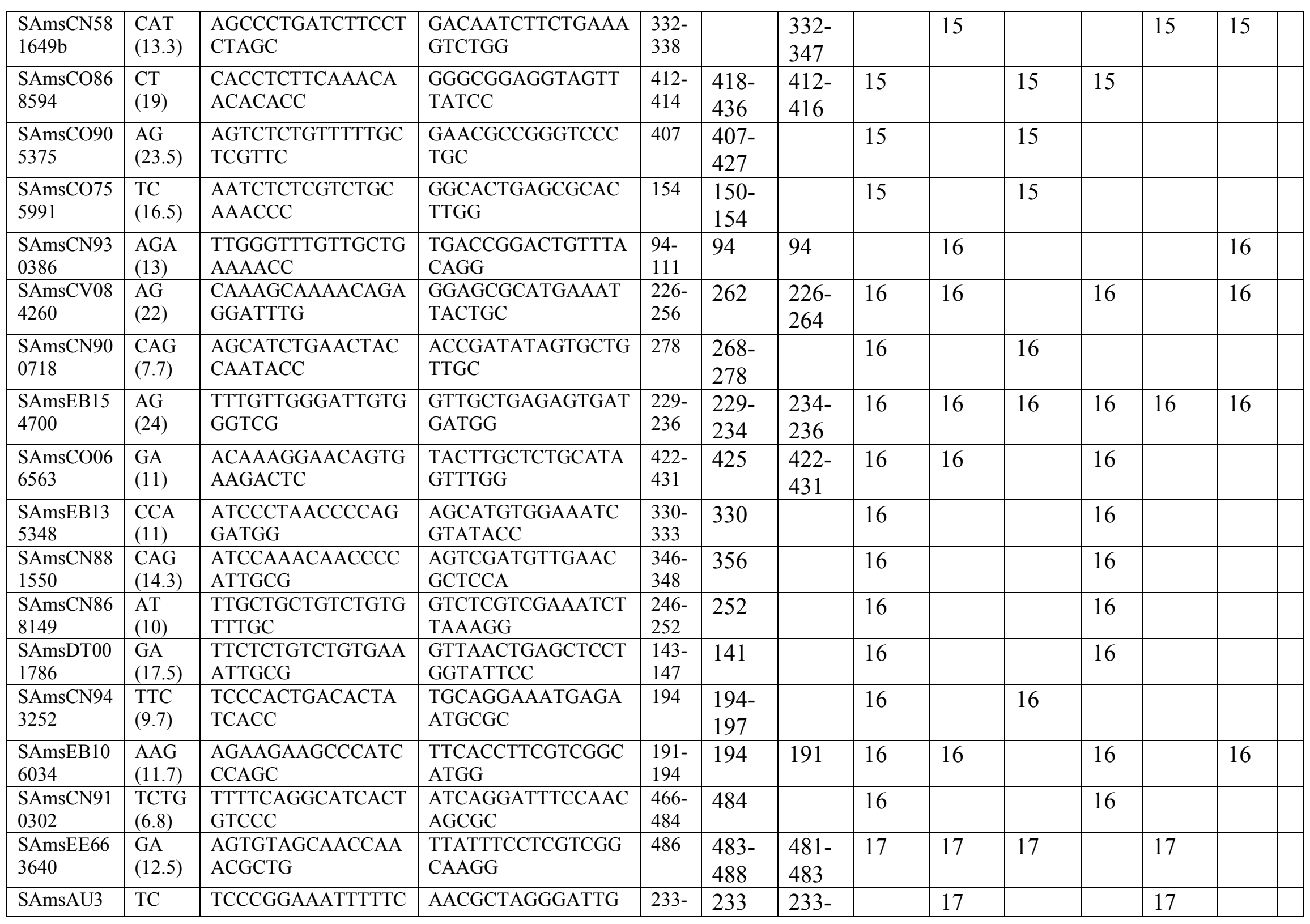




\begin{tabular}{|c|c|c|c|c|c|c|c|c|c|c|c|c|}
\hline 01254 & (15) & AACGC & GTCGC & 246 & & 240 & & & & & & \\
\hline $\begin{array}{l}\text { SAmsCO41 } \\
4947\end{array}$ & $\begin{array}{l}\mathrm{AG} \\
(12)\end{array}$ & $\begin{array}{l}\text { TTTGATTGGACCTG } \\
\text { CAGTGG }\end{array}$ & $\begin{array}{l}\text { TTAGCAGCTGCTTCA } \\
\text { GTGTG }\end{array}$ & $\begin{array}{l}346- \\
350\end{array}$ & $\begin{array}{l}341- \\
354\end{array}$ & & 17 & 17 & 17 & 17 & 17 & 17 \\
\hline $\begin{array}{l}\text { SAmsCN49 } \\
2417\end{array}$ & $\begin{array}{l}\mathrm{TC} \\
(10)\end{array}$ & $\begin{array}{l}\text { TACCATGTTTTAGC } \\
\text { ACCATGG }\end{array}$ & $\begin{array}{l}\text { GGCCAAGTTAGGTC } \\
\text { AAGACG }\end{array}$ & 122 & $\begin{array}{l}122- \\
126\end{array}$ & & 17 & & 17 & & & \\
\hline $\begin{array}{l}\text { SAmsCN49 } \\
0324\end{array}$ & $\begin{array}{l}\mathrm{AG} \\
(16)\end{array}$ & $\begin{array}{l}\text { ATAGAGAGGTAGAG } \\
\text { GACTGG }\end{array}$ & $\begin{array}{l}\text { TTCGCCCAGTGTAAC } \\
\text { ATTGG }\end{array}$ & $\begin{array}{l}230- \\
232\end{array}$ & $\begin{array}{l}223- \\
232\end{array}$ & & 17 & & 17 & 17 & & \\
\hline $\begin{array}{l}\text { SAmsCN93 } \\
8125\end{array}$ & $\begin{array}{l}\text { TTC } \\
(13.7)\end{array}$ & $\begin{array}{l}\text { GCCTTCATCCCCCCT } \\
\text { TGA }\end{array}$ & $\begin{array}{l}\text { GGTGTATAGGAATCT } \\
\text { TGGAG }\end{array}$ & $\begin{array}{l}338- \\
345\end{array}$ & $\begin{array}{l}345- \\
352\end{array}$ & $\begin{array}{l}340- \\
354\end{array}$ & 17 & 17 & 17 & & 17 & 17 \\
\hline $\begin{array}{l}\text { SAmsCN91 } \\
0036\end{array}$ & $\begin{array}{l}\text { CTT } \\
(13.7)\end{array}$ & $\begin{array}{l}\text { GAGAAACCGTTTGA } \\
\text { TTACAGC }\end{array}$ & $\begin{array}{l}\text { CTCCATCCCCAATCA } \\
\text { CACC }\end{array}$ & $\begin{array}{l}235- \\
241\end{array}$ & $\begin{array}{l}232- \\
235\end{array}$ & $\begin{array}{l}220- \\
241\end{array}$ & 17 & 17 & 17 & & 17 & 17 \\
\hline $\begin{array}{l}\text { SAmsCN85 } \\
5917\end{array}$ & $\begin{array}{l}\text { AAT } \\
(15.3)\end{array}$ & $\begin{array}{l}\text { CTCTTTCTTCTCCCT } \\
\text { TCTCC }\end{array}$ & $\begin{array}{l}\text { GATGAGATCCAAAT } \\
\text { CCGTAGT }\end{array}$ & $\begin{array}{l}149- \\
174\end{array}$ & $\begin{array}{l}159- \\
174\end{array}$ & $\begin{array}{l}146- \\
165\end{array}$ & 17 & & 17 & & & \\
\hline $\begin{array}{l}\text { SAmsCN92 } \\
9037\end{array}$ & $\begin{array}{l}\text { TA } \\
(13.5)\end{array}$ & $\begin{array}{l}\text { AGTTGACTACCTCC } \\
\text { TCCGC }\end{array}$ & $\begin{array}{l}\text { GTGGTTCTCACGGTA } \\
\text { CACG }\end{array}$ & $\begin{array}{l}218- \\
225\end{array}$ & $\begin{array}{l}218- \\
239\end{array}$ & $\begin{array}{l}218- \\
220\end{array}$ & 17 & 17 & 17 & & 17 & 17 \\
\hline
\end{tabular}


Table 3 Parameters associated with the QTL for time of initial vegetative budbreak (IVB) identified on LG 9 of the consensus map used for population A and population B, using multiple QTL mapping (MQM)

\begin{tabular}{|c|c|c|c|c|c|c|}
\hline Year & $\mathbf{L O D}^{\mathbf{a}}$ & mu_ac $\{00\}^{b}$ & mu_bc $\{00\}^{b}$ & mu_ad $\{00\}^{b}$ & mu_bd $\{00\}^{b}$ & \% Expl. ${ }^{\mathrm{c}}$ \\
\hline \multicolumn{7}{|c|}{ Population A: 'Golden Delicious' $\mathrm{x}$ 'Anna' } \\
\hline Average & $6.07(6.8)$ & 271 & 271 & 247 & 252 & 36.7 \\
\hline 1999 & $3.1(5.4)$ & 309 & 311 & 285 & 292 & 25.4 \\
\hline 2000 & $3.91(8.9)$ & 307 & 312 & 277 & 302 & 4.8 \\
\hline 2002 & $5.7(4.4)$ & 282 & 279 & 269 & 271 & 23.6 \\
\hline 2004 & $7(4.8)$ & 254 & 254 & 226 & 235 & 40.1 \\
\hline \multicolumn{7}{|c|}{ Population B: 'Sharpe's Early’ x 'Anna'-adult trees } \\
\hline Average & $8.65(7.0)$ & 252 & 262 & 219 & 219 & 41.6 \\
\hline 1996 & $9.52(8.6)$ & 258 & 267 & 221 & 222 & 44.6 \\
\hline 1997 & $8.04(6.1)$ & 254 & 262 & 224 & 222 & 39 \\
\hline 1998 & $6.83(5.3)$ & 245 & 256 & 212 & 212 & 38.2 \\
\hline \multicolumn{7}{|c|}{ Population B: 'Sharpe's Early' x 'Anna'-juvenile trees } \\
\hline Average & $4.68(4.9)$ & 246 & 246 & 226 & 225 & 17.6 \\
\hline 1997 & $2.56(4.5)$ & 260 & 256 & 245 & 242 & 11.9 \\
\hline 1998 & $4.44(4.6)$ & 254 & 255 & 235 & 232 & 20.9 \\
\hline 1999 & $4.49(5.8)$ & 251 & 253 & 230 & 226 & 17.9 \\
\hline
\end{tabular}

${ }^{a}$ Maximum LOD score with considered threshold in parentheses

${ }^{b}$ Estimated mean of the distribution of time of IVB associated with each genotypic class with alleles "a" and " $b$ " inherited from the parental cultivars 'Golden Delicious' and 'Sharpe's Early', respectively, and alleles "c" and "d" inherited from the cultivar 'Anna' ${ }^{c}$ Percentage of the variance explained by the QTL 